\title{
Pore Preservation and Failure Mechanism of Sinian Dengying Formation Carbonate Reservoirs: A Case Study of Two Ultradeep Wells in the Sichuan Basin, Western China
}

\author{
Zeqi Li, ${ }^{1}$ Wei Sun $\mathbb{D}^{1},{ }^{1}$ Shugen Liu $\mathbb{D},{ }^{1,2}$ Zhiwu Li, ${ }^{1}$ Bin Deng, ${ }^{1}$ Juan Wu, ${ }^{1}$ Yi Ding, ${ }^{1}$ Kun Jiao, ${ }^{1}$ \\ Xin Jin, ${ }^{1}$ Pengda Lu, ${ }^{1}$ and Tengzhen Tian ${ }^{1}$ \\ ${ }^{1}$ State Key Laboratory of Oil and Gas Reservoir Geology and Exploitation, Chengdu University of Technology, Chengdu, \\ Sichuan 610059, China \\ ${ }^{2}$ Xihua University, Chengdu, Sichuan 610039, China
}

Correspondence should be addressed to Wei Sun; sunweicdut@163.com and Shugen Liu; lsg@cdut.edu.cn

Received 20 April 2021; Revised 17 September 2021; Accepted 5 October 2021; Published 15 November 2021

Academic Editor: Jian Hou

Copyright (c) 2021 Zeqi Li et al. This is an open access article distributed under the Creative Commons Attribution License, which permits unrestricted use, distribution, and reproduction in any medium, provided the original work is properly cited.

\begin{abstract}
Despite being one of the most important factors in deep oil and gas exploration, the preservation mechanisms of ultradeep carbonate reservoirs remain poorly understood. This study performed thin-section, geochemistry, field emission scanning electron microscopy, fluid inclusion, and basin model analysis of samples from two boreholes over 8,000 $\mathrm{m}$ deep in the Sichuan Basin to determine the pore features and preservation mechanism of the Sinian (Ediacaran) Dengying Formation carbonate reservoirs. The reservoir of CS well \#1 is characterised by pore diameters larger than a centimetre (average porosity $7.48 \%$; permeability $0.8562 \mathrm{mD}$ ), and the pores are mainly filled with dolomite or bitumen. In contrast, the reservoir of MS well \#1 is predominantly composed of micron-scale residual pores (average porosity $1.74 \%$; permeability $0.0072 \mathrm{mD}$ ), and the pores are typically filled with dolomite, bitumen, and multistage quartz. The burial thermal histories suggest that both reservoirs were subjected to high pressure (i.e., pressure coefficient $>1.5$ ) before the Late Cretaceous. However, the pressure coefficient of the reservoir of MS well \#1 has decreased to less than 1.0 owing to strong structural adjustment this well since the Late Cretaceous, which allowed other ore-forming fluids to enter and fill the pores, resulting in further compaction of the pores. In contrast, the pressure coefficient of CS well \#1 is 1.1-1.2, which effectively prevented other ore-forming fluids from entering and filling the pores. The findings show that the dynamic adjustment of the Dengying Formation palaeo-gas reservoir indirectly affects the preservation or failure of the reservoir. The occurrence and geometry of bitumen in the Dengying reservoir exhibit good consistency with the pressure changes in both boreholes. In particular, bitumen with an annular shape and contraction joints in reservoir pores is widespread in CS well \#1, which is attributed to the continuous preservation of palaeo-gas fields. Conversely, bitumen with a broken particle shape is located among the epigenetic minerals widespread in MS well \#1, which is attributed to failure and depletion of the palaeo-gas fields.
\end{abstract}

\section{Introduction}

Ultradeep carbonate oil/gas exploration (i.e., at depths greater than $5,000 \mathrm{~m}$ ) is attracting increasing attention among petroleum geologists [1-4]. Recent exploration has achieved promising results in deep to ultradeep carbonate formations, e.g., the Mills Ranch gas field, with a depth of 7,663-8,103 m [5-7], the Anyue gas field in the Sichuan
Basin, which is over $6,000 \mathrm{~m}$ deep, and Tahe oil field in the Tarim Basin, with a depth of more than 6,000 $\mathrm{m}$ [6-9].

For ultradeep exploration, the most important factor is a high-quality reservoir; this is because of the substantial reduction in the porosity and permeability of rocks with depth [10]. Moreover, strata below 4,000-5,000 m exhibit heterogeneous porosity [10-12]. As a result, the preservation and destruction mechanisms of ultradeep carbonate 


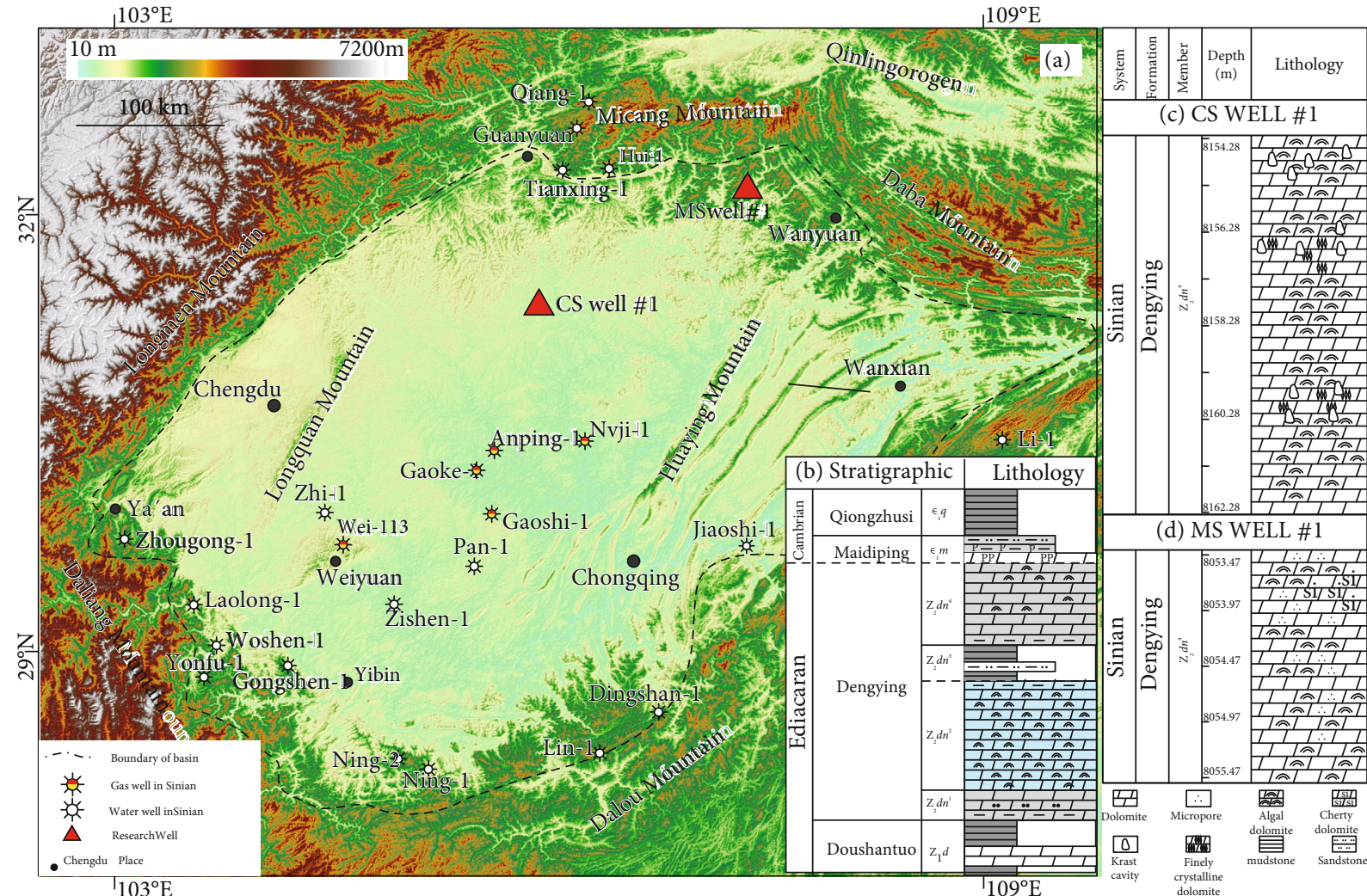

Figure 1: (a) Digital elevation model showing the topography and locations of gas and water wells in the Upper Neoproterozoic Dengying Formation across the Sichuan Basin and surroundings. (b) Lithologic histogram of Dengying Formation of Sinian system in Sichuan Basin. (c) Lithologic histogram of a core section of the Sinian Dengying Formation from CS well \#1. (d) Lithologic histogram of a core section of the Sinian Dengying Formation from MS well \#1.

reservoirs, for example, burial dissolution associated with hydrocarbon generation [13, 14], are poorly known [15-17]. The acidic fluid in carbonate reservoirs formed by $\mathrm{H}_{2} \mathrm{~S}$ and $\mathrm{CO}_{2}$ can lead to thermochemical sulphate reduction (TSR), which can improve or preserve reservoir quality $[13,14,18,19]$. Furthermore, deep hydrothermal fluids related to normal fault activity can facilitate the formation of hydrothermal dolomite reservoirs, for example, in North America and the Middle East [20, 21]. However, some researchers argue that deep to ultradeep reservoirs are characterised by a closed system of fluid flow (e.g., pore water flow) and geochemistry, indicating that the total porosity remains unchanged $[15,22,23]$. It should be noted that acidic or hydrothermal fluids will also lead to a large amount of cementation $[15,23,24]$. Therefore, research and discussion on the preservation mechanism of ultradeep carbonate reservoir have theoretical and practical significance.

The Sichuan Basin, located in the South China continental block, is one of the largest sedimentary basins in China and is rich in petroleum resources (Figure 1). A major hydrocarbon deposit in the Sinian Dengying Formation was discovered in the Anyue gas field at a depth of approximately $6,000 \mathrm{~m}$, with a volume of $4,403.8 \times 10^{8} \mathrm{~m}^{3}(15.6 \mathrm{tcf})$ $[25,26]$. The nearby PT well \#1, with a depth of $\sim 7,000 \mathrm{~m}$, records production of $130 \times 10^{4} \mathrm{~m}^{3}$ per day. The Dengying Formation is a typical ultradeep reservoir (Figure 1)
[27-29] that provides an excellent case study for analysing the pore preservation and failure mechanisms in ultradeep high-quality dolomite reservoirs. However, there is lack of study on ultradeep carbonate reservoirs (depth $>8000 \mathrm{~m}$ ) in current research, which makes the preservation mechanism of carbonate reservoirs in ultradeep extreme conditions remains unknown. Recently, two boreholes were drilled in the northern Sichuan Basin to target the Dengying Formation, that is, MS well \#1 and CS well \#1, with depths of $8,044 \mathrm{~m}$ and $8,146 \mathrm{~m}$, respectively. In this study, we investigate the Sinian Dengying carbonate reservoirs using samples from these two boreholes, as well as analyses based on thin sections, geochemistry, field emission scanning electron microscopy, fluid inclusions, basin models, etc. The findings suggest that (1) the dynamic adjustment of palaeo-gas controls the preservation or failure of ultradeep carbonate reservoirs, and (2) the occurrence and geometry of bitumen in the Dengying reservoir show good consistency with pressure changes in both boreholes.

\section{Geological Setting}

The Sichuan Basin is located along the northwest margin of the South China Block, which is a part of the Precambrian Rodinia supercontinent $[30,31]$. The Sinian/Ediacaran sedimentary rocks represent the early sedimentary history of the 
Sichuan Basin, of which the Denying Formation comprises shallow-water dolomitic carbonates. Because of the Tongwan tectonic movement during the Late Edicarian, the Dengying dolomites were exposed to freshwater karstification, resulting in widespread development of caverns and dissolution porosity, especially along unconformities on the top of the Dengying Formation (Figure 1) [19, 32]. These dolomites became crucial for petroleum accumulation in the Proterozoic Dengying Formation (Figure 1), as demonstrated by widespread bitumen and proven gas reserves of $408.61 \times 108 \mathrm{~m}^{3}(1.5 \mathrm{tcf})$ and $4,403.8 \times 108 \mathrm{~m}^{3}$ (15.6 tcf) in the Weiyuan and Anyue gas fields, respectively [25]. During the Mesozoic to Cenozoic periods, this area experienced several phases of tectonic movement, including the Caledonian, Indosinian, and Yashanian movements $[33,34]$. The Caledonian tectonic phase in this region resulted in erosion of most of the upper Silurian, Devonian, and Carboniferous strata across the South China Block. East-west striking Leshan-Longnvshi palaeo-uplift formed in the basin centre during the Caledonian movement. Palaeo-uplift had an important influence on hydrocarbon accumulation during the Triassic to Jurassic across the Sichuan Basin [35-37]. The Indosinian and Yashanian movements resulted in the formation of complex foreland basins from the Late Triassic to Cretaceous, such as the western Sichuan and northern Sichuan basins [38, 39].

Both CS well \#1 and MS well \#1 are located in the northern Sichuan Basin (Figure 1(a)). The total drilling depth of CS well \#1 is $8,448 \mathrm{~m}$, with $302 \mathrm{~m}$ cutting of the Dengying Formation, whereas that of MS well $\# 1$ is $8,418 \mathrm{~m}$, with $374 \mathrm{~m}$ cutting of the Dengying Formation. In general, the Dengying Formation can be divided into four members from bottom to top: Deng-1 $\left(\mathrm{Z}_{2} \mathrm{dn}^{1}\right)$, Deng-2 $\left(\mathrm{Z}_{2} \mathrm{dn}^{2}\right)$, Deng-3 $\left(\mathrm{Z}_{2} \mathrm{dn}^{3}\right)$, and Deng-4 $\left(\mathrm{Z}_{2} \mathrm{dn}^{4}\right)$ (Figure $\left.1(\mathrm{~b})\right)$ based on lithology and algal abundance [27, 40-42]. Despite the lack of large framework biota, the main building groups of the biological community in the $\mathrm{Z}_{2} \mathrm{dn}^{2}$ and $\mathrm{Z}_{2} \mathrm{dn}^{4}$ members are microorganisms, bacteria, and algae $[26,43]$. The $Z_{2} \mathrm{dn}^{1}$ member is characterised by micrite dolomite, whereas the $\mathrm{Z}_{2} \mathrm{dn}^{3}$ member, which is deposited in semi-open shore facies, is characterised by bluish-grey argillaceous siltstone and black shale intercalated with thin-layer dolomite [7, 44]. In contrast, the $Z_{2} \mathrm{dn}^{2}$ and $Z_{2} \mathrm{dn}^{4}$ members are mainly composed of algal microbial dolomite (Figure 1(b)). Algal dolomites with botryoidal and stromatolite dominate $\mathrm{Z}_{2} \mathrm{dn}^{2}$, whereas light-grey to white massive algal dolomite and silt-crystal dolomite dominate $\mathrm{Z}_{2} \mathrm{dn}^{4}[45,46]$.

\section{Samples and Experimental Methods}

3.1. Samples. The coring sections of the Dengying Formation in CS well \#1 and MS well \#1 are located near the top of the $\mathrm{Z}_{2} \mathrm{dn}^{4}$ member. The CS well \#1 coring section lies between $8,154.28 \mathrm{~m}$ and $8,162.28 \mathrm{~m}$ and provided a total of 55 cores. The following 48 samples were obtained from these cores: 30 thin sections (including eight for fluid inclusion observation), six samples for high-pressure mercury injection, and 12 samples for field emission scanning electron microscopy (FESEM). The MS well \#1 coring section lies between
$8,053.47 \mathrm{ma}$ and $8,055.47 \mathrm{~m}$ and has provided 18 cores in total. The following 24 samples were collected: 16 thin sections (including four for fluid inclusion observation), three samples for high-pressure mercury injection, and five samples for FESEM.

3.2. Methods. High-pressure mercury injection (HPMI) can provide excellent porosity, permeability, median pressure, migration pressure, skewness coefficient, and maximum mercury saturation estimates [3]. HPMI was performed on nine samples (i.e., six samples in CS well \#1 and three samples in MS well \#1) using the AutoPore 9510 IV mercury injection apparatus at the State Key Laboratory of Oil and Gas Reservoir Geology and Exploitation. Prior to HPMI, the dolomite samples were cleaned with ethanol and dried under vacuum at $150^{\circ} \mathrm{C}$ for at least $12 \mathrm{~h}$. The maximum injection pressure was $340.528 \mathrm{MPa}$.

FESEM-focused ion beam analysis was performed at the State Key Laboratory of Oil and Gas Reservoir Geology and Exploitation using the field emission scanning electron microscope Quanta 250 FEG (US FEI) and energy spectrum analyser Oxford InCAX-MAX20 (UK Oxford) on 17 samples. First, the samples were prepared in a square column of approximately $10 \times 10 \times 5 \mathrm{~mm}$, and the surface was coated with a thin gold layer using an EM SCD500 ion sputtering device (Leica, Wetzlar, Germany). Second, the minerals were observed and analysed using a Quanta 250 FEG scanning electron microscope at $23^{\circ} \mathrm{C}$ and $35 \%$ humidity according to the National GBBT 17361-2013 national standard. Third, the observed minerals were analysed using an Oxford InCAX-MAX20 energy spectrum analyser for qualitative or semiquantitative microregion compositions.

Fluid inclusion observations can provide extensive information on the diagenetic mineralisation and infilling conditions of palaeo-fluids [47-49], particularly the palaeopressure of reservoirs and gas fields [50-53]. In this study, 12 thin sections were observed. The homogenisation and ice temperatures of the fluid inclusions were measured on a linkam-TH600 hot and cold platform. The homogenisation temperatures of the two-phase saline inclusions (containing hydrocarbons) were also determined. The initial temperature rise rate of the uniform temperature measurement was $10^{\circ} \mathrm{C} / \mathrm{min}$, which was then reduced to $1^{\circ} \mathrm{C} / \mathrm{min}$; the accuracy of the uniform temperature measurement was $\pm 1^{\circ} \mathrm{C}$.

\section{Results}

\subsection{Petrology and Pore Characteristics of Reservoirs}

4.1.1. Petrology. The $\mathrm{Z}_{2} \mathrm{dn}^{4}$ member in CS well \#1 is predominantly composed of microbial algal dolomite, with laminae and an algal-clay structure (Figures 2(a) and 2(c)), some fine-grained dolomite (Figure 2(d)), rich in filamentary irregular dark algae (Figure 2(e)), globular clusters/aggregates (Figures 2(c) and 2(e)), and millimetre-scale straightwrinkle lamina (Figure 2(a)). From bottom to top, the sedimentary sequence transitions from a subtidal microbial mound shoal to an intertidal microbial mat with a cycle thickness of $1-3 \mathrm{~m}$, indicating that the sedimentary 

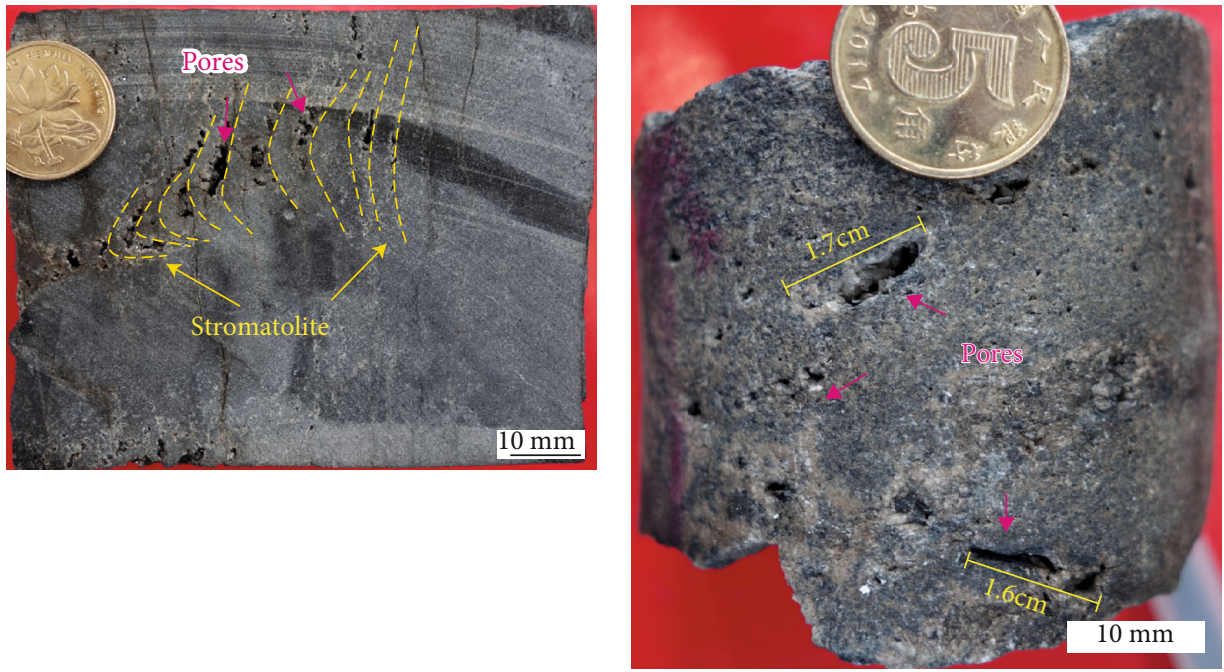

(a)

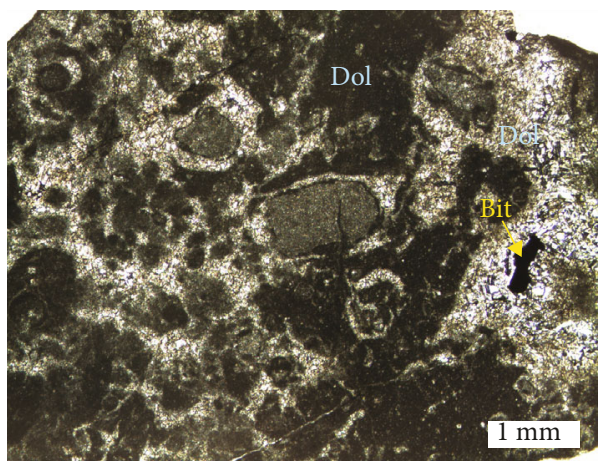

(c)

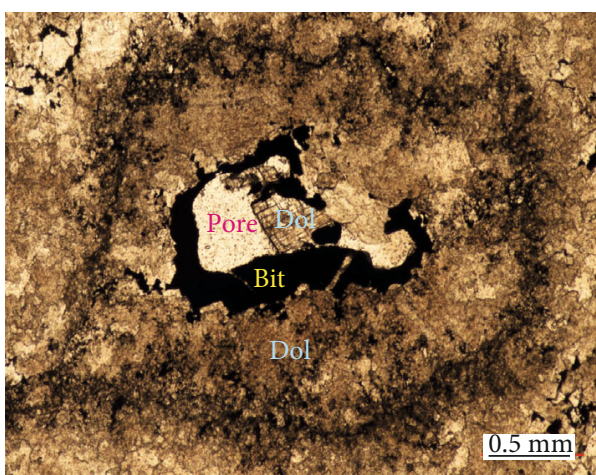

(e) (b)

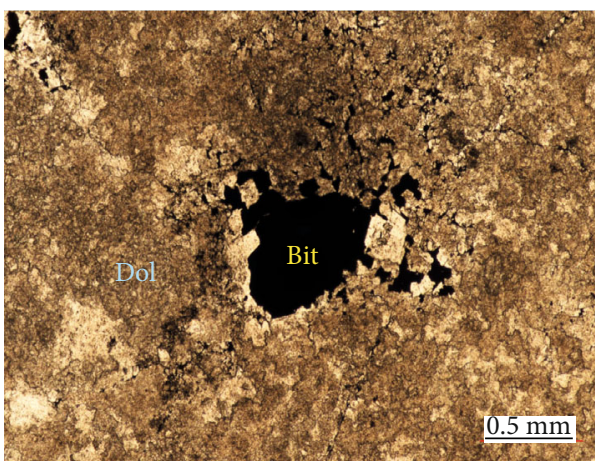

(d)

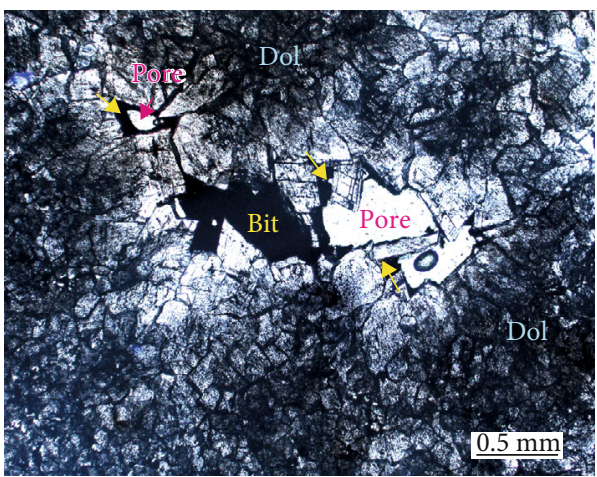

(f)

FIGURE 2: Lithology and pore characteristics of the CS well \#1 $\mathrm{Z}_{2} \mathrm{dn}^{4}$ member reservoir. (a) Algae stratiform dolomite, solution pore-fracture distribution along the algae stratiform stack, CS well \#1, 8,160.29-8,160.36 m; (b) algae-coagulated dolomite; cm- and mm-scale pore/solution pore development, CS well \#1, 8,157.96-8,158.07 m; (c) algae-coagulated dolomite, solution pores developed in the finegrained dolomite cement between microbial fabrics, fully filled with bitumen, CS well \#1, 8,162.15 m; (d) solution pores developed in crystalline powder dolomite, fully filled with bitumen, CS well \#1,8,157.96 m; (e) pulverised dolomite solution pores, recrystallised dolomite and bitumen semi-filled dissolution pores, hollow centre, CS well \#1, 8,159.12 m; (f) pulverised dolomite intergranular solution pores, bitumen semifilled solution pores, hollow centre, CS well \#1, 8,159.95 m.

microfacies are typical low-energy tidal flats of carbonate shallow water.

The $\mathrm{Z}_{2} \mathrm{dn}^{4}$ member in MS well \#1 is dominated by algaerich laminae and condensed dolomite (Figures 2(a) and 2(e)), with some silicified dolomite (Figures 2(c) and 2(d)) and a lamellar structure between the bright and dark phases
(Figure 3(a)). In general, the lithology is similar to that of the CS well \#1 $\mathrm{Z}_{2} \mathrm{dn}^{4}$ member, and the sedimentary microfacies are microbial algal mound shoals.

4.1.2. Pore Characteristics. Core observations revealed widespread millimetre- to centimetre-scale solution pores in the 


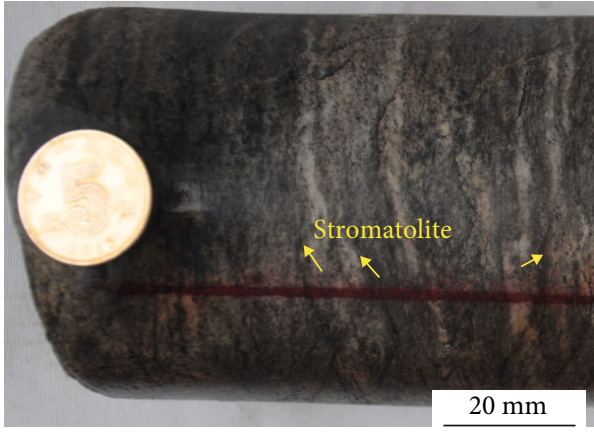

(a)

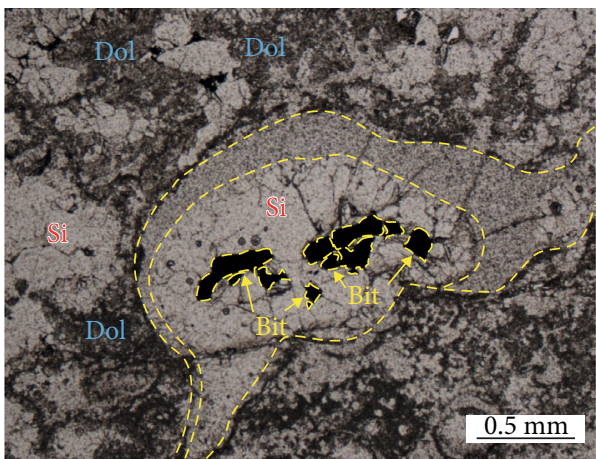

(c)

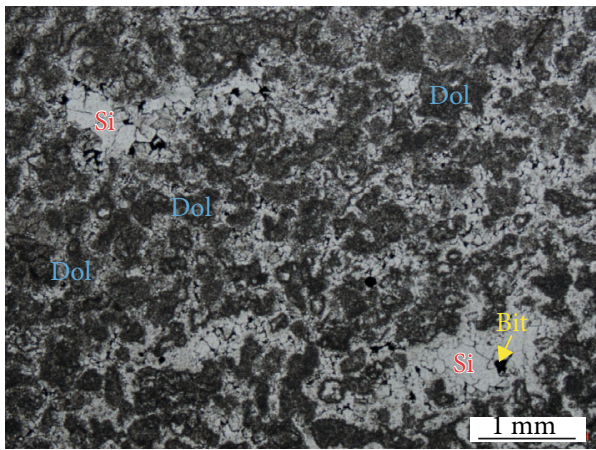

(e)

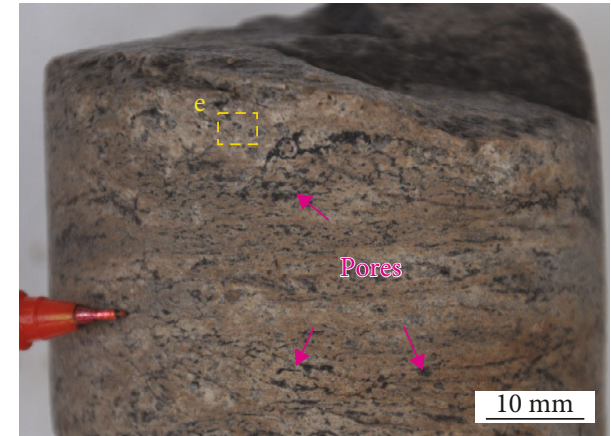

(b)

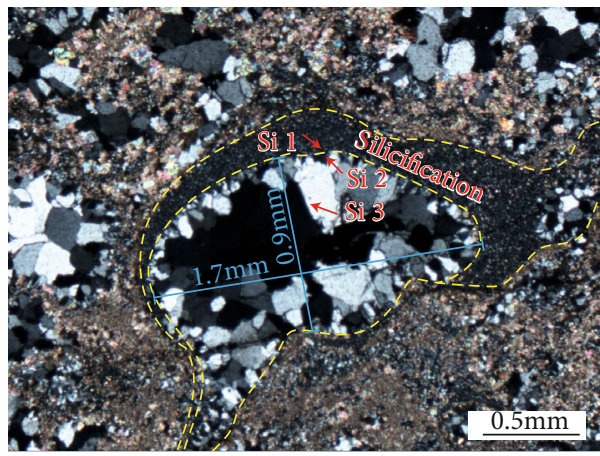

(d)

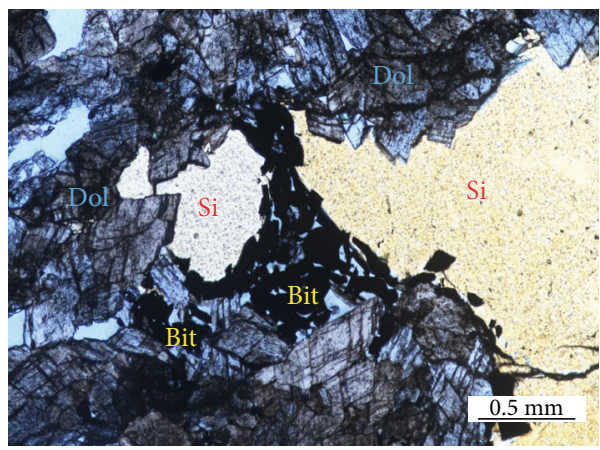

(f)

Figure 3: Lithology and pore characteristics of MS well \#1 $\mathrm{Z}_{2} \mathrm{dn}^{4}$ member reservoir. (a) Stratiform algal dolomite, MS well \#1, 8,053.87$8,054.64 \mathrm{~m}$; (b) needle-like micropores, MS well \#1, 8,053.47-8,053.87 m; (c) solution pores with a pore size of approximately $0.9 \times 1.7$ $\mathrm{mm}$ filled with minerals, MS well \#1,8,053.99 m; (d) orthogonal polarised photo of c; (e) algae-condensed dolomite, where the original lattice hole was strongly silicified, MS well $\# 1,8,054.46 \mathrm{~m}$; (f) intergranular solution pores of recrystallised dolomite, semi-filled with bitumen particles and authigenic quartz, MS well \#1, 8,056.19 m.

CS well \#1 $\mathrm{Z}_{2} \mathrm{dn}^{4}$ member (Figures $2(\mathrm{a})$ and $2(\mathrm{~b})$ ), which can be divided into two categories: (1) dissolved pores along microlayers (Figure 2(a)) and the residual structure of algal lamina; (2) partly isolated, elliptical, and irregular centimetre-scale solution pores (Figure 2(b)), e.g., microbial fabric solution pores (Figure 2(c)), fine-grained dolomite intergranular pores, and intergranular solution pores (Figures 2(d)-2(f)). The minerals in the pores are mainly composed of multistage dolomite (Figures 2(c) and 2(f)) and bitumen (Figures $2(\mathrm{~d})$ and $2(\mathrm{e})$ ). The bitumen is predominantly annular, and the pore centre is hollow (Figures 2(e) and 2(f) and Figures 4(c) and 4(f)). The overall facial porosity rate is approximately $2 \%-12 \%$, and the pore size ranges from approximately $0.02 \times 0.03 \mathrm{~mm}$ to $9 \times 27 \mathrm{~mm}$.
The cores of MS well \#1 are characterised by needle tiplike micropores (Figure 3(b)), rather than centimetre- or millimetre-scale pores. In the thin section, there are dark irregular filamentous or bubble-like aggregates, along with a large number of destroyed and transformed algal microbial lattice pores (Figure 3(e)). In general, the latticed holes are strongly damaged and transformed, and the original pore structure is difficult to identify. However, the morphology of the early developed millimetre-scale corrosion holes before partial filling or destruction is still visible, as shown in Figures 3(c) and 3(d). The maximum original pore size is approximately $0.9 \times 1.7 \mathrm{~mm}$, and the pores are fully filled by multiple minerals. Figure 3(f) shows the intergranular solution pores at the millimetre-scale pore size after the 


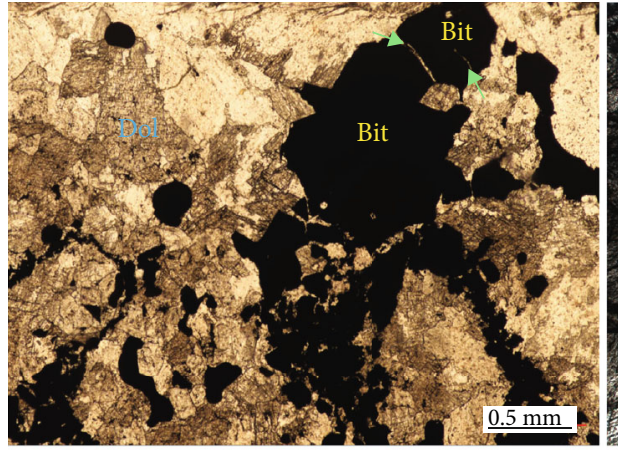

(a)

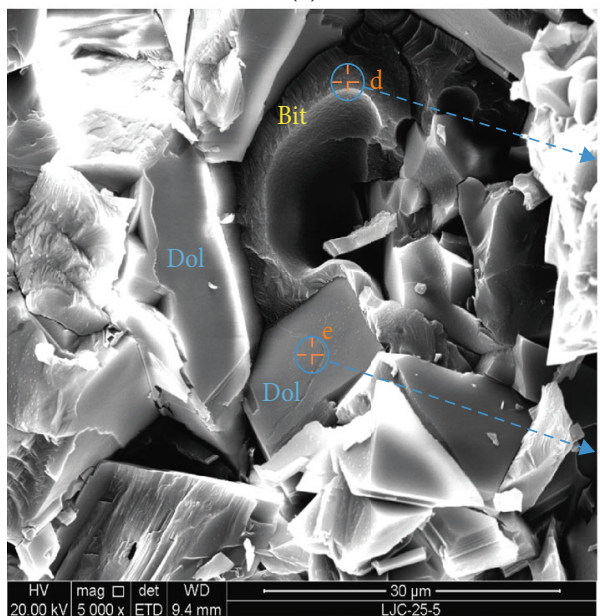

(c)

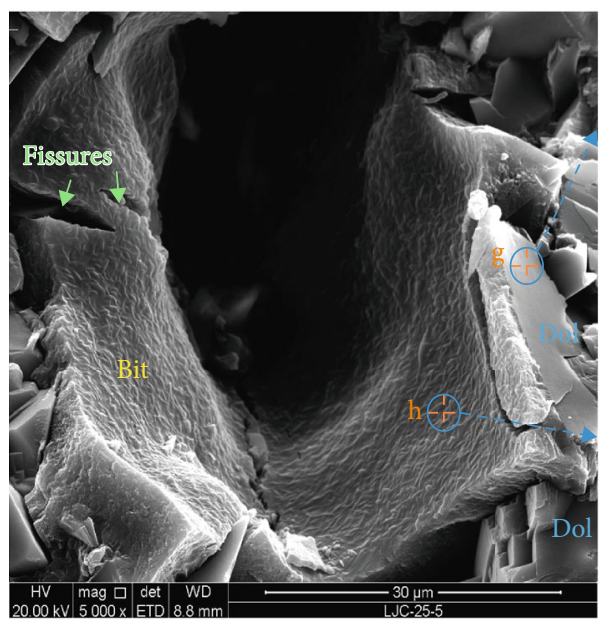

(f)

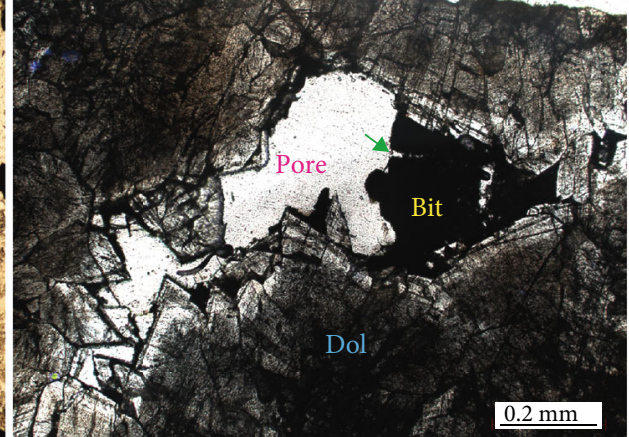

(b)

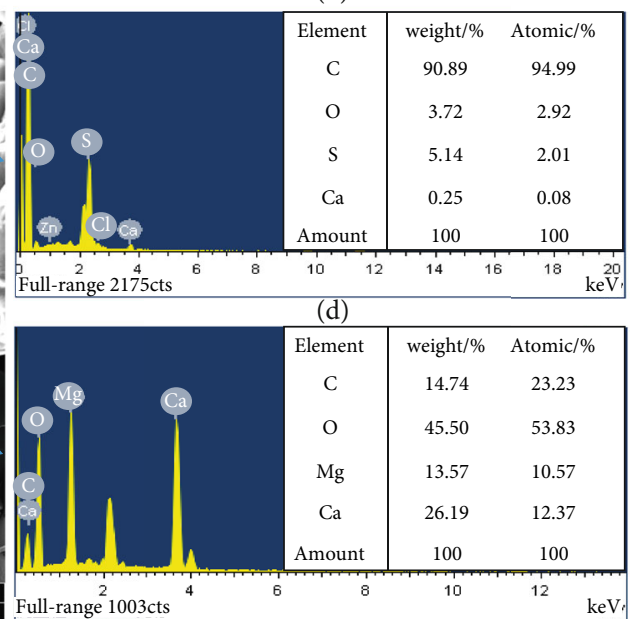

(e)

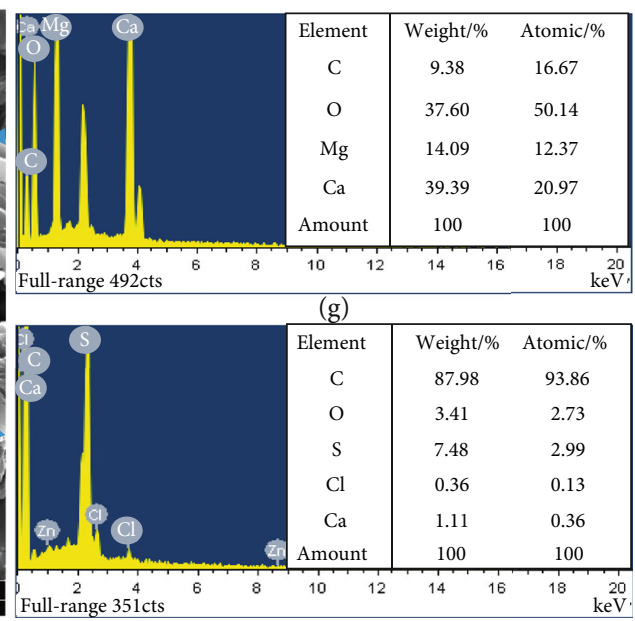

(h)

FIGURE 4: Chart of pore and filling mineral morphology of the CS well \#1 $\mathrm{Z}_{2} \mathrm{dn}^{4}$ member. (a) Bitumen is displayed as a patchy filling, and the contracted interval cracks of bitumen are mostly visible (sample depth is $8,161.07 \mathrm{~m}$ ); (b) semifilling of bitumen in intergranular solution pores (sample depth is $8,154.39 \mathrm{~m}$ ); (c) bitumen filling in recrystallised dolomite intergranular solution pores, where bitumen morphology is annular and attached to the cave wall (sample depth is $8,157.79 \mathrm{~m}$ ); (d) and (e) diagram of principal component analysis of minerals; (f) bitumen in the solution pores is attached to the wall of the hole in a ring shape, and the morphology of bitumen is complete. Two contracted interval cracks are visible (sample depth is $8,159.62 \mathrm{~m}$ ); $(\mathrm{g})$ and $(\mathrm{h})$ analysis of the main mineral components in $(\mathrm{d})$.

remaining micron-scale pores were filled with a variety of minerals. The original morphology of the pores is poorly preserved, with broken boundaries crushed by different minerals and the development of pore deformation traces (Figures $5(\mathrm{a})-5(\mathrm{j}))$. Thus, the overall facial porosity rate is approximately $1 \%-2 \%$.
4.1.3. Multistage Minerals in Pores. The pore-filling minerals in the CS well \#1 $\mathrm{Z}_{2} \mathrm{dn}^{4}$ member reservoir are primarily recrystallised dolomite and bitumen (Figures 2(d)-2(f)). The recrystallised fine-grained dolomite in the solution pores is predominantly self-crystallised (Figures 2(e) and 2(f) and Figure 4(b)), with some exhibiting evidence of 


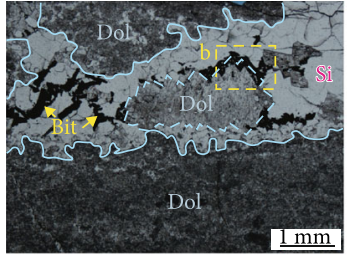

(a)

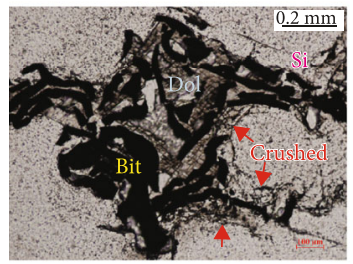

(d)

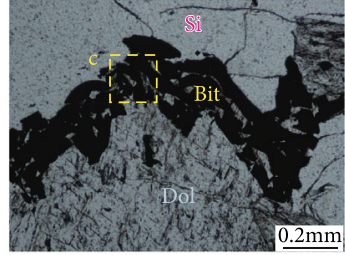

(b)

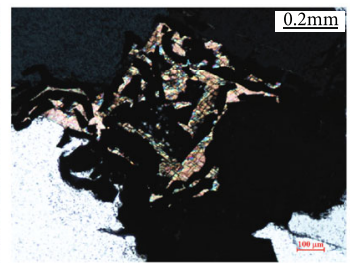

(e)

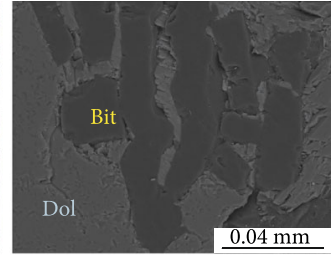

(c)

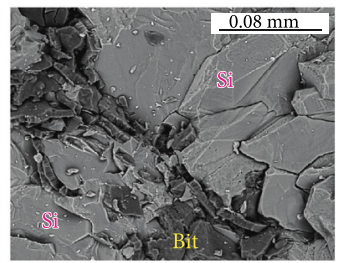

(f)

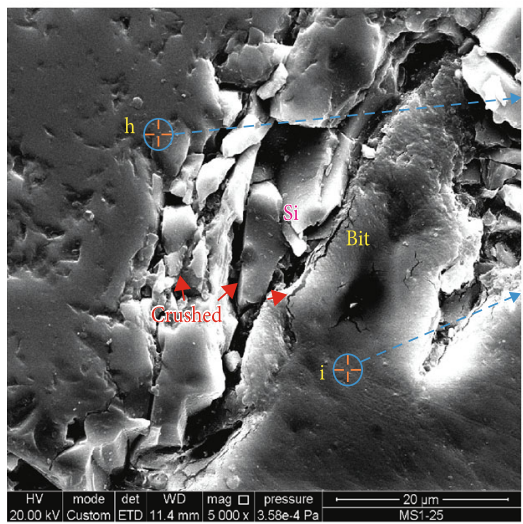

(g)

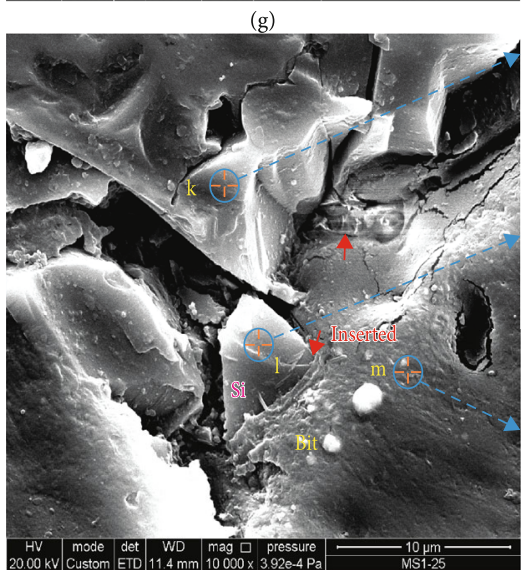

(j)
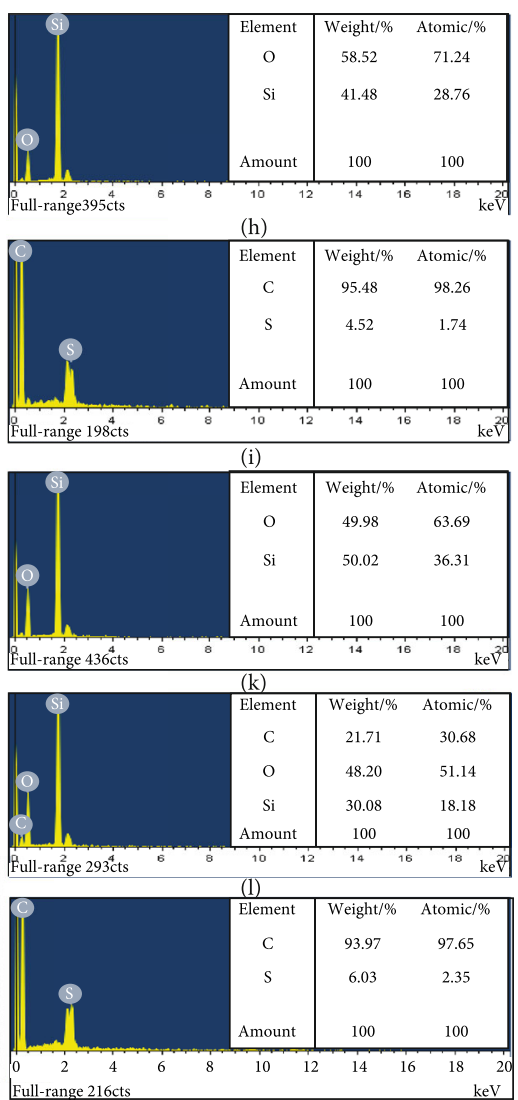

$(\mathrm{m})$

FIGURE 5: Chart of pore and filling mineral morphology of the MS well \#1 $\mathrm{Z}_{2} \mathrm{dn}^{4}$ member. (a) Interior of solution pore with a pore size exceeding $2 \mathrm{~mm}$, fully filled with authigenic quartz, recrystallised dolomite and bitumen. Among them, recrystallised dolomite has a large crystal size, good crystal shape, and granular bitumen morphology; bitumen is scattered between the grains of authigenic quartz or between the grains contacted by authigenic quartz and dolomite (sample depth is $8,055.32 \mathrm{~m}$ ); (b) close up of part (a), where the contact relationship of minerals shows that bitumen is distributed in granular form between authigenic quartz and recrystallised dolomite crystals, and some bitumen is embedded in the contact crystal; (c) close up of (b), showing broken granular bitumen; (d) several minerals in the pores are closely contacted, and the recrystallised dolomite with good crystal form is extruded and broken. Bitumen particles are mostly distributed within or between the crystals of other epigenetic minerals in the shape of extrusion embedding, and crushing cracks are more likely on the boundary of authigenic quartz crystal (sample depth is $8,053.97 \mathrm{~m}$ ); (e) orthogonal polarisation of part (d); (g) contact relationship of minerals in pores under scanning electron microscope, in which the bending deformation and compressive cracks are more visible on the bitumen boundary contacting with quartz, and the extrusion fracture zone is more visible on the edge of autogenous quartz grains (sample depth is $8,055.16 \mathrm{~m}$ ); (h) and (i) qualitative analysis of authigenic quartz and bitumen mineral composition in part $(\mathrm{g}) ;(\mathrm{j})$ bending deformation and compressive cracks of bitumen are more obvious, and broken quartz is inserted into bitumen (sample depth is $8,054.16 \mathrm{~m}) ;(\mathrm{k})-(\mathrm{m})$ qualitative analysis of authigenic quartz and bitumen mineral composition in part (j). 


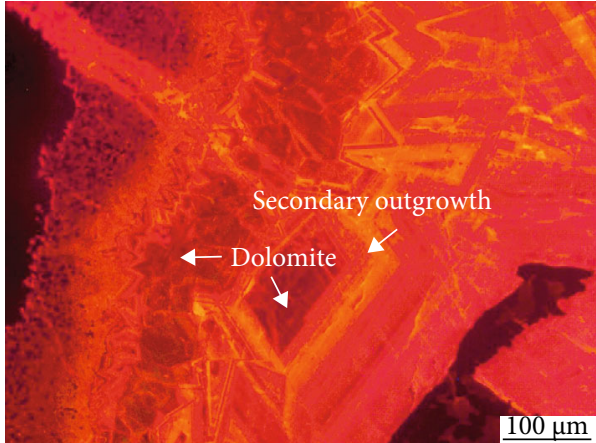

(a)

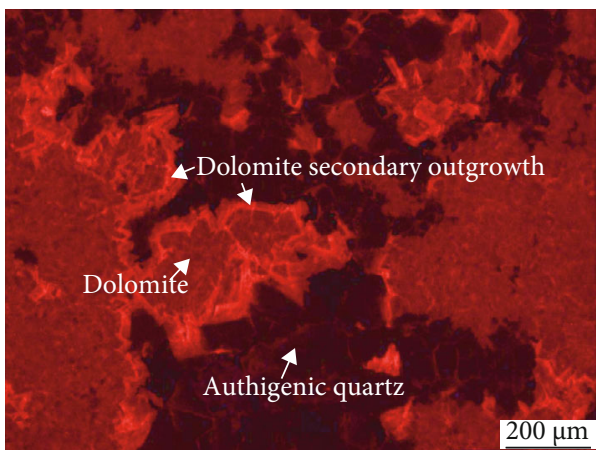

(c)

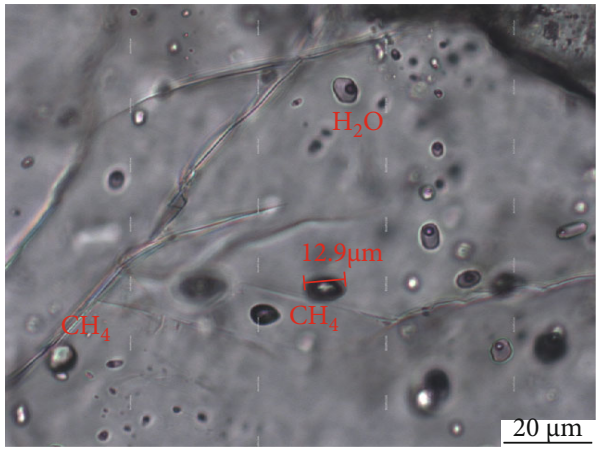

(e)

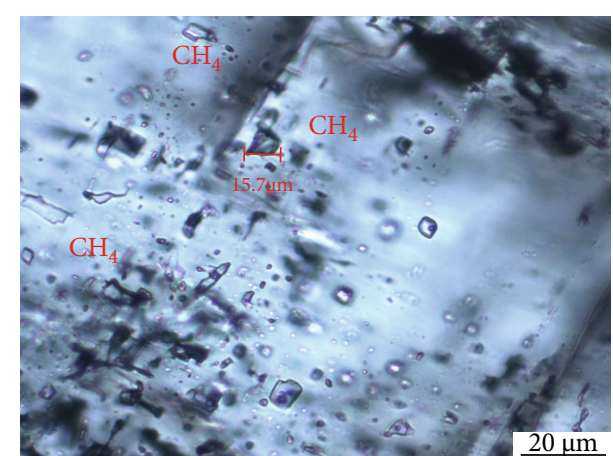

(b)

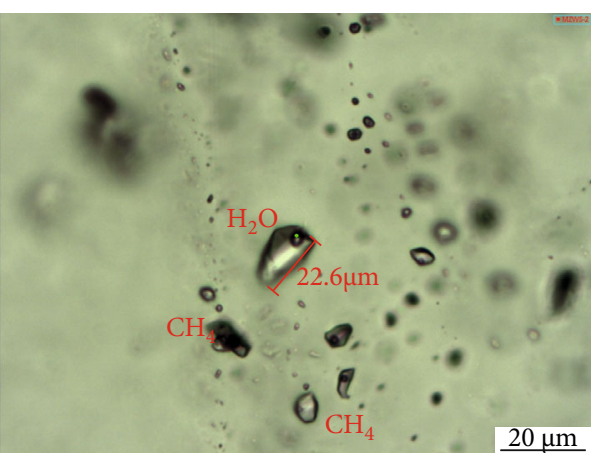

(d)

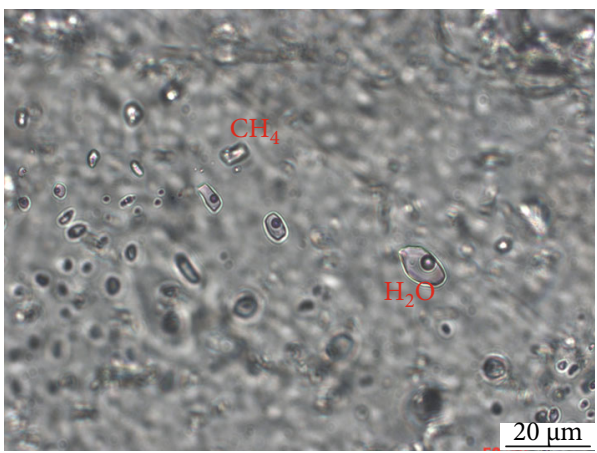

(f)

FIGURE 6: Microscopic characteristics of fluid inclusion distribution and type of $Z_{2} \mathrm{dn}^{4}$ member in the study area. (a) and (b) Images of CS well \#1 fluid inclusion distribution area and type (sample depth is $8,159.12 \mathrm{~m}$ ); (c)-(f) images of MS well \#1 fluid inclusion distribution area and type (sample depth is $8,055.27 \mathrm{~m}$ ).

secondary enlargement (Figure 6(a)). Most pores are filled with bitumen (Figure 2(d)). Dry cracks and postthermal cracking shrinkage cracks of the bitumen are clearly observed (Figure 2(e) and Figures 4(a), 4(c), and 4(f)), indicating that the bitumen was retained in situ after thermal cracking. Overall, the multistage mineral filling sequence of the CS well \#1 $\mathrm{Z}_{2} \mathrm{dn}^{4}$ member pores is as follows: firstgeneration recrystallised fine dolomite, second-generation bitumen, and/or third-generation dolomite secondary outgrowth filling (Figure 2(e) and Figures 4(a) and 4(b)).

The pores of the MS well \#1 $\mathrm{Z}_{2} \mathrm{dn}^{4}$ member are strongly reformed, and the primary pore structure is substantially reformed. The filling minerals in the pores are predominantly silicified dolomite, bitumen, recrystallised dolomite, and authigenic quartz. Some early pore structures are also observed (Figures 3(c) and 3(d) and Figure 5(a)), indicating high-quality primary pores in MS well \#1. As shown in Figures 5(a)-5(c), authigenic quartz with three-stage growth is observed in ultralarge solution pores, with a crystal diameter of approximately $2.3 \mathrm{~mm}$ and a regular crystal shape. Furthermore, multistage growth of bitumen and quartz is also found in the pores (Figure 3(c)). This suggests that the original pore space is large enough to allow selfcrystallisation and precipitation of fluid minerals in later stages. The characteristics of the growth filling sequence of multistage quartz in the pores are as follows: first-stage dentate authigenic quartz, second-stage secondary quartz, and third-stage quartz enlargement edge (Figures 3(c) and $3(\mathrm{~d}))$. The contact boundary between some authigenic quartz particles and other minerals (such as bitumen or 
TABLE 1: Statistics of major mercury pressure parameters in two core sections of $Z_{2} \mathrm{dn}^{4}$.

\begin{tabular}{|c|c|c|c|c|c|c|}
\hline Well number & Depth $(\mathrm{m})$ & Lithology & Porosity (\%) & Permeability (mD) & Median pressure $(\mathrm{MPa})$ & Median radius $(\mu \mathrm{m})$ \\
\hline CS 1 & $8,155.79$ & Algal doloarenite & 12.17 & 0.4646 & 2.35 & 0.68 \\
\hline CS 1 & $8,157.18$ & Algal doloarenite & 5.67 & 1.0297 & 4.96 & 0.49 \\
\hline CS 1 & $8,158.16$ & Algal clotted dolomite & 2.51 & 0.0439 & 6.55 & 0.33 \\
\hline CS 1 & $8,159.51$ & Micritic-aplite dolomite & 10.62 & 2.0368 & 1.01 & 0.86 \\
\hline CS 1 & $8,160.98$ & Micritic-aplite dolomite & 6.42 & 0.6477 & 4.79 & 0.50 \\
\hline CS 1 & $8,161.59$ & Algal doloarenite & 7.51 & 0.9145 & 3.04 & 0.51 \\
\hline MS 1 & $8,053.87$ & Algal doloarenite & 2.65 & 0.0110 & 23.61 & 0.09 \\
\hline MS 1 & $8,054.64$ & Algal doloarenite (siliceous) & 1.37 & 0.0097 & 39.03 & 0.06 \\
\hline MS 1 & $8,054.91$ & Algal doloarenite & 1.21 & 0.0011 & 44.25 & 0.02 \\
\hline
\end{tabular}

dolomite) exhibits clear indications of crushing (Figures 5(a)-5(e)). FESEM observations reveal that the quartz crushing particles were extruded into the bitumen (Figures $5(\mathrm{~g})$ and $5(\mathrm{j})$ ). Therefore, the morphology of the bitumen in the pores is typically broken, granular, and scattered, distributed between secondary quartz or recrystallised dolomite grains (Figures 3(c) and 3(d) and Figures 5(a), 5(c), and $5(\mathrm{~d})$ ), in which the effective pores remain partly accumulated by grains and bitumen particles (Figure 3(f)). In general, the multistage mineral filling sequences in the pores of MS well \#1 are as follows: first-generation recrystallised dolomite, second-generation bitumen, third-generation dentate authigenic quartz, fourth-generation quartz, and fifthgeneration dolomite.

\subsection{High-Pressure Mercury Injection}

4.2.1. Physical Parameters. HPMI test analysis of the nine core samples reveals a porosity range for the CS well \#1 $\mathrm{Z}_{2} \mathrm{dn}^{4}$ member sample of $2.17 \%-12.17 \%$, with an average value of $7.48 \%$. Permeability ranges from $0.0439 \mathrm{mD}$ to $2.0368 \mathrm{mD}$, with an average of $0.8562 \mathrm{mD}$ (Table 1). The porosity of the MS well \#1 $\mathrm{Z}_{2} \mathrm{dn}^{4}$ member sample ranges from $1.21 \%$ to $2.65 \%$, with an average of $1.74 \%$, and the permeability ranges from 0.0011 to $0.0110 \mathrm{mD}$, with an average of $0.0072 \mathrm{mD}$. Thus, the porosity and permeability of MS well \#1 are inferior to those of CS well \#1.

4.2.2. Pore-Throat Characteristics. The HPMI curves of the nine samples exhibit different shapes and characteristics (Figure $7(\mathrm{a})$ ). The average median radius of the pore throat of the CS well \#1 $\mathrm{Z}_{2} \mathrm{dn}^{4}$ member sample is $0.33-0.86 \mu \mathrm{m}$, with a median pressure of 1.01-6.55 MPa (Table 1). Almost no platform section is observed in the mercury injection curve; however, the mercury intake rate is good, with a maximum exceeding 90\% (Figure 7(a)). Among the pore throats, $64.08 \%$ have a radius of $0.16-1.6 \mu \mathrm{m}$, indicating a large porethroat size range and high connectivity (Figure $7(\mathrm{~b})$ ).

The average pore-throat radius of the MS well \#1 $\mathrm{Z}_{2} \mathrm{dn}^{4}$ member sample is $0.03-0.09 \mu \mathrm{m}$, and the median pressure is 23.61-44.65 MPa (Table 1). The maximum mercury saturation is only $55 \%$ (Figure $7(\mathrm{a})$ ), and the median pressure is $44.25 \mathrm{MPa}$. The pore-throat radius range of $0-0.1 \mu \mathrm{m}$ accounts for $83.83 \%$ of all pore throats, indicating a micropore-throat size range and low connectivity (Figure 7(b)). In general, CS well \#1 exhibits a better average median radius and lower median pressure and more connectivity than MS well \#1.

4.3. Fluid Inclusions. Three types of fluid inclusions are observed in the samples: gas-liquid two-phase inclusions, pure liquid inclusions, and pure gas inclusions, with gas-liquid two-phase inclusions being dominant. Gas and gas-liquid two-phase inclusions are found in local mineral crystals, indicating that they were trapped at the same time. Inclusions are banded or grouped and distributed in recrystallised dolomite, secondary outgrowth of dolomite, and authigenic quartz (Figures 6(a) and 6(c)), with elliptical (round), strip, approximately square, and irregular shapes. In general, the inclusions exhibit a small gas/liquid ratio (less than $20 \%$ ), and the inclusion diameter is typically $10-25 \mu \mathrm{m}$ (Figures 6(b)-6(f)). It should be noted that hydrocarbon inclusions can be subdivided into liquid-oil inclusions and gas-phase methane inclusions according to their phase states and compositions. Liquid-oil inclusions are mainly distributed in the secondary outgrowth of dolomite and appear dark brown and yellow brown under transmission single polarised light (Figures 6(b) and 6(d)). Gas-phase methane inclusions occur predominantly in dolomite secondary outgrowths and authigenic quartz. Under a polarising microscope, they appear mostly grey in colour, with a bright line observed in the middle. These inclusions are generally $9-20 \mu \mathrm{m}$ in size and often star-scattered. These inclusions are mostly symbiotic with brine inclusions (Figures 6(e) and 6(f)).

The homogenisation temperature of fluid inclusions in the CS well \#1 $\mathrm{Z}_{2} \mathrm{dn}^{4}$ member exhibits multiple peaks at $80-85^{\circ} \mathrm{C}, \quad 110-125^{\circ} \mathrm{C}, \quad 150-185^{\circ} \mathrm{C}$, and $200-220^{\circ} \mathrm{C}$ (Figures 8(a) and 8(c)). Among them, the peak homogenisation temperature of inclusions in recrystallised dolomite is $110-125^{\circ} \mathrm{C}$, whereas that of secondary outgrowth inclusions in dolomite is $150-185^{\circ} \mathrm{C}$ and $200-220^{\circ} \mathrm{C}$. The homogenisation temperatures of inclusions in MS well \#1 are also characterised by multiple peaks at $75-90^{\circ} \mathrm{C}, 100-145^{\circ} \mathrm{C}, 150-$ $180^{\circ} \mathrm{C}, \quad 185-220^{\circ} \mathrm{C}, \quad 245-285^{\circ} \mathrm{C}, \quad$ and $\quad 295.0-315^{\circ} \mathrm{C}$ (Figures 8(b) and 8(d)). Among them, the homogenisation temperature of the recrystallisation dolomite inclusions is $100-145^{\circ} \mathrm{C}$, that of the recrystallisation dolomite secondary 


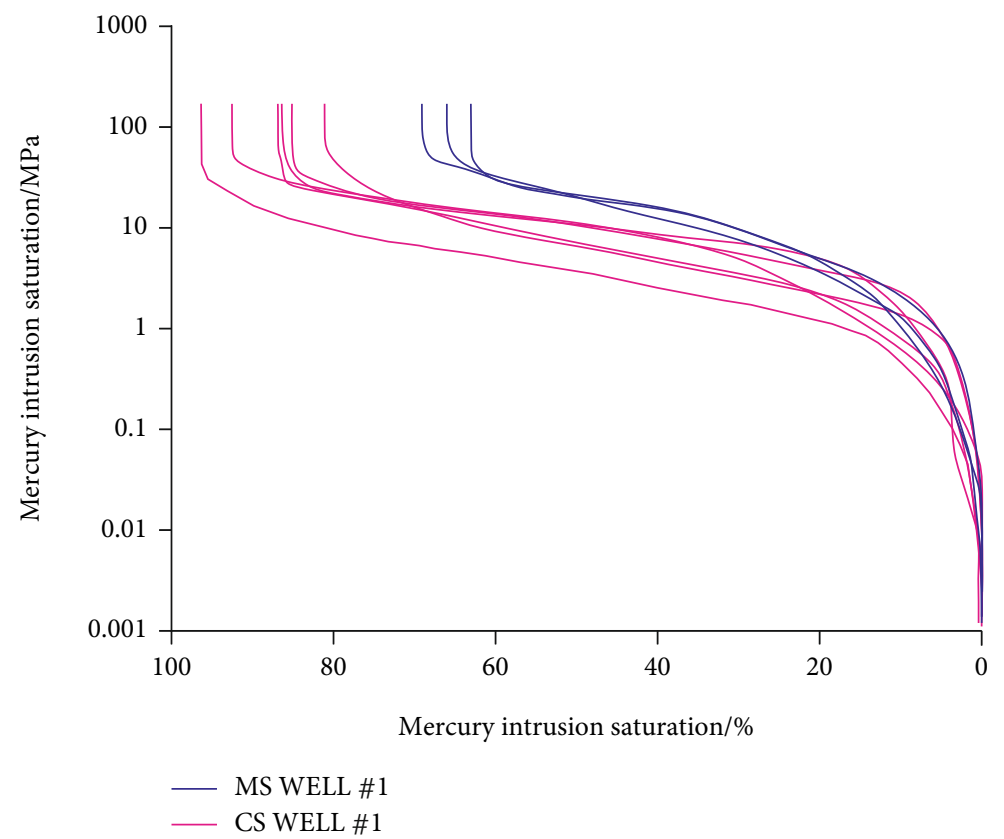

(a)

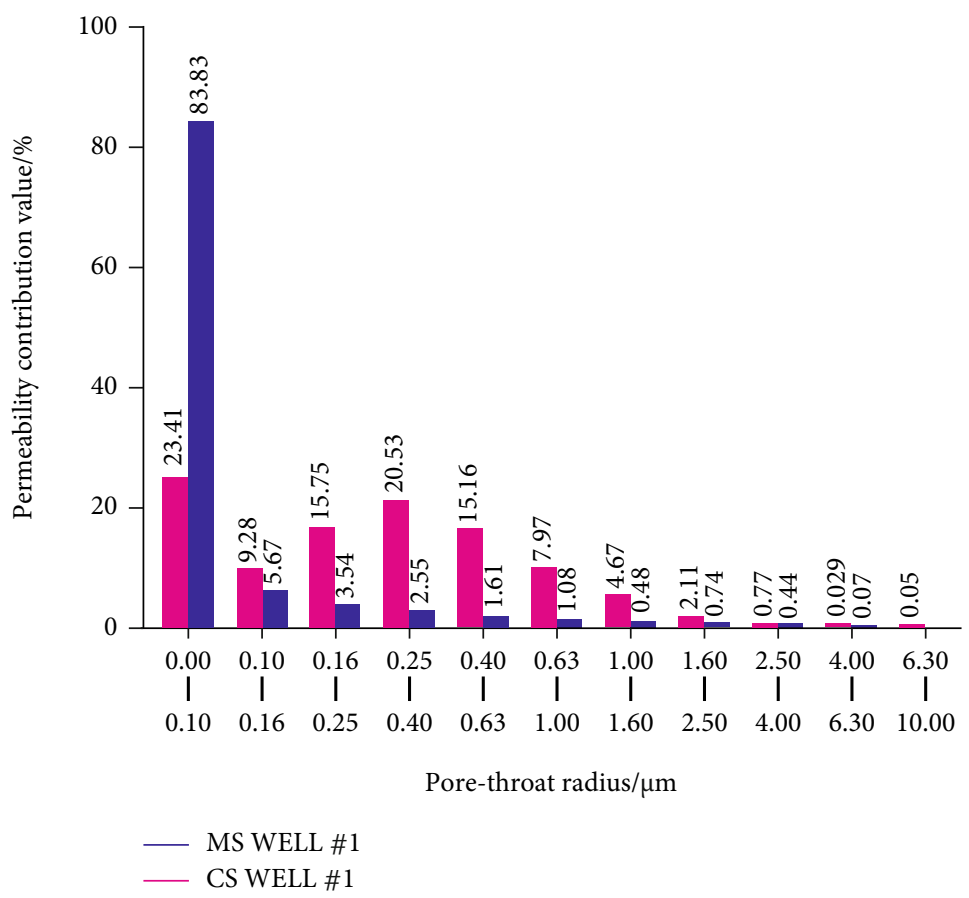

(b)

FigURE 7: HPMI curves of $\mathrm{C}$ well \#1 and MS1 well \#1 $\mathrm{Z}_{2} \mathrm{dn}^{4}$ member, and distribution of pore-throat radii. (a) HPMI curves of nine samples. (b) Histogram of pore-throat radius distribution.

outgrowth inclusions is $150-180^{\circ} \mathrm{C}$, that of authigenic quartz inclusions is $295.0-312^{\circ} \mathrm{C}$, that of secondary quartz inclusions grown in the first stage is $248-282^{\circ} \mathrm{C}$, and that of secondary quartz enlarged edge inclusions grown in the second stage is $185-221^{\circ} \mathrm{C}$.

The trapping pressure of fluid inclusions in $\mathrm{Z}_{2} \mathrm{dn}^{4}$ can be calculated by the functional relationship between the homogenisation temperature of the inclusions, freezing point tem- perature, and salinity [50-53]. The palaeo-fluid pressure coefficient (Table 2) can be further calculated by combining the palaeo-burial depth (see following section for details). The palaeo-pressure coefficient of the CS well \#1 $\mathrm{Z}_{2} \mathrm{dn}^{4} \mathrm{mem}$ ber is 1.10-1.46, with a median of 1.1-1.2, indicating weak overpressure in the $\mathrm{Z}_{2} \mathrm{dn}^{4}$ member. The palaeo-pressure coefficient of MS well \#1 $Z_{2} \mathrm{dn}^{4}$ member formation was 0.88-1.43, with a median of $0.9-1.1$, indicating normal pressure. 


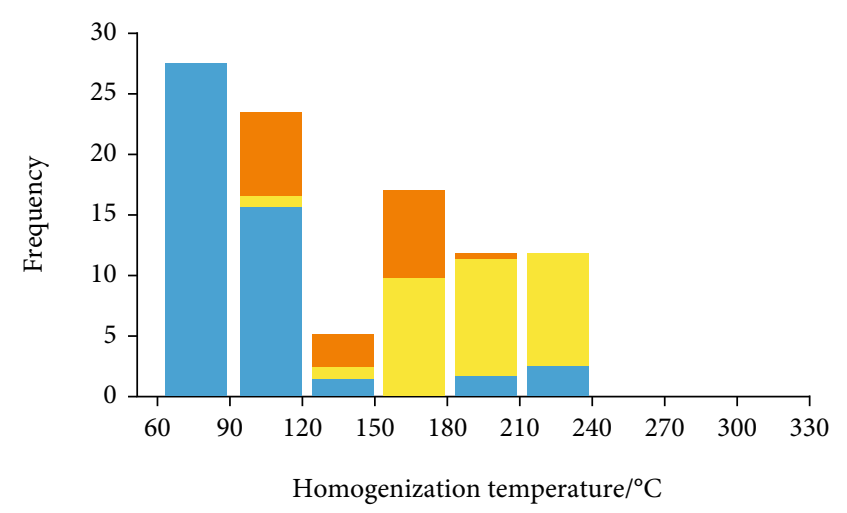

Aqueous inclusion

- Organic inclusion

- Petroleum inclusion

(a)

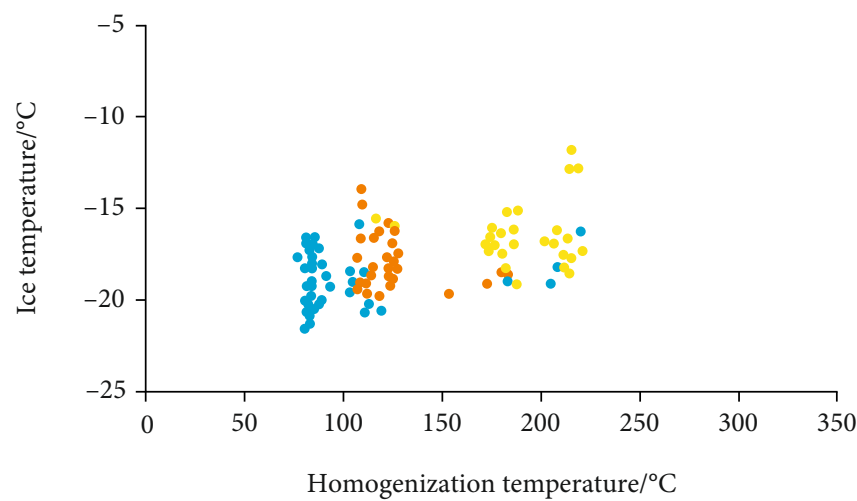

(c)

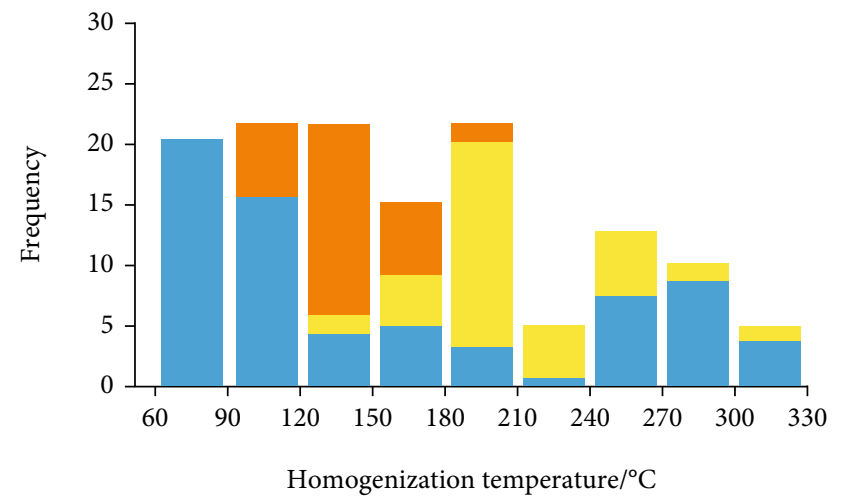

(b)

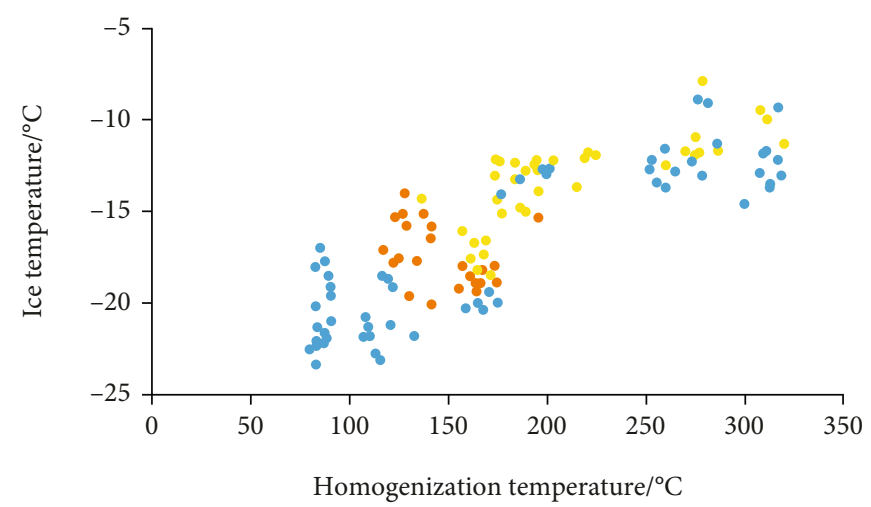

(d)

FIGURE 8: Relationship between homogenisation temperature and salinity of fluid inclusions. (a) Frequency histogram of homogenisation temperature for CS well \#1; (b) frequency histogram of homogenisation temperature for MS well \#1; (c) uniform-temperature salinity diagram of CS well \#1 inclusions; (d) uniform-temperature salinity diagram of MS well \#1 inclusions.

\section{Burial Thermal History and Palaeo- Pressure of the Dengying Formation}

BasinMod-1D software was used to reconstruct the burial and thermal histories of CS well \#1 and MS well \#1 (Figure 9) by integrating the stratigraphic thickness, lithology, absolute age, measured borehole temperature, and vitrinite reflectance (Table 3). The total organic content (TOC) in the core samples was further measured using a LECO CS-200 analyser. Table 3 lists all the results for the 13 core samples from CS well \#1 and MS well \#1. CS well \#1 the vitrinite reflectance values (\%Ro) range from $2.01 \%$ to $2.22 \%$, and the TOC values range from $1.70 \%$ to $4.36 \%$. MS well \#1 vitrinite reflectance values (\%Ro) and TOC values range from $2.21 \%$ to $4.65 \%$ and $0.71 \%$ to $6.04 \%$, respectively. The modelling process was calibrated using the thermal maturity of the formation and borehole temperatures, combined with the Easy\% Ro method [54] and the NULL chemical kinetic model [55]. According to the burial histories of CS well \#1 and MS well \#1 (Figure 9), the palaeo-pressure coefficient was further calculated using the fluid inclusion data, and the palaeo-pressure evolution characteristics of the two wells were obtained by combining the data of fluid trapping times to reconstruct key events (Figure 10).
The burial depth thermal history of CS well \#1 can be divided into three stages (Figures 9(a) and 10(a)).

(1) From the early Permian to early Triassic palaeoreservoir formation period, the overlying strata of the Dengying Formation gradually thickened, the Lower Cambrian source rocks entered the oil generation stage, crude oil migrated to the reservoir through the top unconformity surface of the Dengying Formation (Figure 10(a)), and the homogenisation temperature of the reservoir trapping inclusions ranged from $113.4^{\circ} \mathrm{C}$ to $123.7^{\circ} \mathrm{C}$. Furthermore, the palaeo-pressure coefficient was 1.1-1.2, which indicates normal pressure and weak overpressure

(2) From the Middle Triassic to Late Triassic, the homogenisation temperature of the reservoir trapping inclusions ranged from $153.2^{\circ} \mathrm{C}$ to $184.7^{\circ} \mathrm{C}$, and the palaeopressure coefficient was $1.20-1.46$, indicating highpressure enrichment characteristics (Figure 10(b))

(3) During the continuous preservation period of gas reservoirs from the Middle Jurassic to the present, the palaeo-gas reservoirs continued to evolve into 
TABle 2: Major data from the fluid inclusion analysis (modified from [25]).

\begin{tabular}{|c|c|c|c|c|c|c|c|c|}
\hline Well & $\begin{array}{c}\text { Palaeo-burial } \\
\text { depth }(\mathrm{m})\end{array}$ & $\begin{array}{c}\text { Host } \\
\text { mineral }\left({ }^{\circ} \mathrm{C}\right)\end{array}$ & $\begin{array}{c}\text { Ice point } \\
\text { temperature }\left({ }^{\circ} \mathrm{C}\right)\end{array}$ & Amount & $\begin{array}{l}\text { Homogenisation } \\
\text { temperature }\end{array}$ & $\begin{array}{l}\text { Salinity } \\
(\%)\end{array}$ & $\begin{array}{c}\text { Trapping } \\
\text { pressure }(\mathrm{MPa})\end{array}$ & $\begin{array}{l}\text { Pressure } \\
\text { coefficient }\end{array}$ \\
\hline \multirow{4}{*}{ CS 1} & $\begin{array}{c}3,780.95- \\
4,195.24\end{array}$ & $79.4-88.1$ & -13.2 to -19.8 & 29 & Dolomite & $\begin{array}{c}22.23- \\
17.07\end{array}$ & $51.59-46.70$ & $1.10-1.18$ \\
\hline & $\begin{array}{c}4,300.00- \\
5,312.50\end{array}$ & $103.2-127.5$ & -10.5 to -10.8 & 39 & Dolomite & $\begin{array}{c}14.16- \\
21.32\end{array}$ & $51.67-65.88$ & $1.12-1.24$ \\
\hline & $\begin{array}{c}6,383.33- \\
7,808.34\end{array}$ & $153.2-184.7$ & -17.0 to -16.3 & 24 & $\begin{array}{c}\text { Dolomite of } \\
\text { recrystallisation }\end{array}$ & $\begin{array}{c}15.47- \\
20.22\end{array}$ & $66.61-78.88$ & $1.21-1.46$ \\
\hline & $\begin{array}{c}8,760.87- \\
9,569.57\end{array}$ & $201.5-220.1$ & -8.3 to -16.3 & 18 & $\begin{array}{c}\text { Dolomite of } \\
\text { recrystallisation }\end{array}$ & $\begin{array}{c}12.04- \\
14.68\end{array}$ & $88.35-132.10$ & $1.13-1.19$ \\
\hline \multirow{6}{*}{$\begin{array}{l}\text { MS } \\
1\end{array}$} & $\begin{array}{c}3,780.95- \\
4,195.24\end{array}$ & $78.5-88.5$ & -11.3 to -22.6 & 19 & Dolomite & $\begin{array}{c}15.27- \\
24.08\end{array}$ & $46.22-52.35$ & $1.09-1.20$ \\
\hline & $\begin{array}{c}5,293.76- \\
5,983.33\end{array}$ & $104.5-143.6$ & -10.5 to -22.1 & 29 & Dolomite & $\begin{array}{c}14.46- \\
23.76\end{array}$ & $49.76-63.41$ & $1.07-1.29$ \\
\hline & $6,087.5-7,379.17$ & $153.0-177.1$ & -13.2 to -19.7 & 16 & $\begin{array}{l}\text { Dolomite of } \\
\text { recrystallisation }\end{array}$ & $\begin{array}{c}17.07- \\
22.17\end{array}$ & $74.98-107.70$ & $1.19-1.49$ \\
\hline & $\begin{array}{c}12,291.67- \\
12,987.50\end{array}$ & $295.0-311.7$ & -5.1 to -7.1 & 9 & Authigenic quartz & $\begin{array}{l}8.00- \\
11.80\end{array}$ & $110.11-145.17$ & $1.02-1.11$ \\
\hline & $10,316.66-11,750$ & $247.6-282$ & -4.2 to -7.0 & 17 & Secondary quartz & $\begin{array}{l}6.63- \\
10.48\end{array}$ & $80.84-108.36$ & $0.88-1.03$ \\
\hline & $\begin{array}{c}8,516.67- \\
9,220.83\end{array}$ & $185.4-221.3$ & -5.1 to -9.3 & 20 & Secondary quartz & $\begin{array}{l}8.00- \\
13.17\end{array}$ & $59.20-81.01$ & $0.89-1.12$ \\
\hline
\end{tabular}

dry gas, with uplift erosion since the Late Cretaceous. The homogenisation temperature of reservoir trapping inclusions ranged from $201.5^{\circ} \mathrm{C}$ to $220.1^{\circ} \mathrm{C}$, and the palaeo-pressure coefficient was 1.1-1.2, denoting weak pressure adjustment and release characteristics

The thermal history process and accumulation evolution of the MS well \#1 $\mathrm{Z}_{2} \mathrm{dn}^{4}$ member can also be divided into three periods (Figures 9(b) and 10(b)).

(1) The Late Silurian to the Middle Permian saw the formation and overpressure enrichment stage of the palaeo-oil reservoir. With the opening of the hydrocarbon generation threshold and the entry of crude oil into the pores, the homogenisation temperature range of fluid inclusions trapped in the Dengying Formation reservoir was $104.5-143.6^{\circ} \mathrm{C}$, and the pressure coefficient was $1.20-1.29$, which is characteristic of weak overpressure (Figure 10(a)). From the Late Triassic to Late Cretaceous, with continued deepening of burial strata, the palaeo-burial depth of the Dengying Formation increased to more than $6,000 \mathrm{~m}$, and crude oil in the palaeo-oil reservoir began to crack to form natural gas. The inclusion temperature range was $153.0-177.1^{\circ} \mathrm{C}$, and the abnormal pore pressure increased rapidly. The pressure coefficient reached 1.49, indicating an overpressurised system (Figure 10(b))

(2) The Late Cretaceous marked the stage of gas reservoir adjustment dissipation and pressure release. With rapid uplift and erosion of Micang Mountain, the MS well \#1 area, which is located at the front edge of the Micang Mountain, was tilted strongly towards the mountain. Natural gas rapidly dissipated towards the Micang Mountain along the unconformity at the top of the Dengying Formation, and the formation pressure rapidly adjusted and decreased. Other fluids then entered the pores, which along with the formation uplift and temperature decrease, reduced the homogenisation temperature of fluid inclusions trapped by the reservoir from 295.0$311.7^{\circ} \mathrm{C}$ to $247.6-282^{\circ} \mathrm{C}$. The pressure coefficient ranged from 0.88 to 1.03

(3) During the Cenozoic pressure reaccumulation stage, as the erosion rate slowed in the Micang Mountain area and formation of the Tongnanba structure was completed, the formation pressure reaccumulated to normal pressure. The corresponding homogenisation temperature range of the inclusions was 185.4$221.3^{\circ} \mathrm{C}$, and the pressure coefficient was $1.02-1.12$

\section{Discussion}

6.1. Pore Formation Mechanism of the Dengying Formation. CS well \#1 and MS well \#1 $\mathrm{Z}_{2} \mathrm{dn}^{4}$ members were dominated by microbial algal dolomite and algal lamina and revealed the development of algal clot structures (Figure 2(a) and Figure 3(a)). CS well \#1 exhibited solution pores distributed along the algal laminae (Figures 2(a) and 2(b)). The residual morphology of microbial algae fabric pores was observed on both the macro and microscale (Figures 2(c) and 2(e); Figures 3(a) and 3(e)), and late-stage reformation was strong, reflecting the control factors of early microbial mound shoal formation on favourable reservoirs 


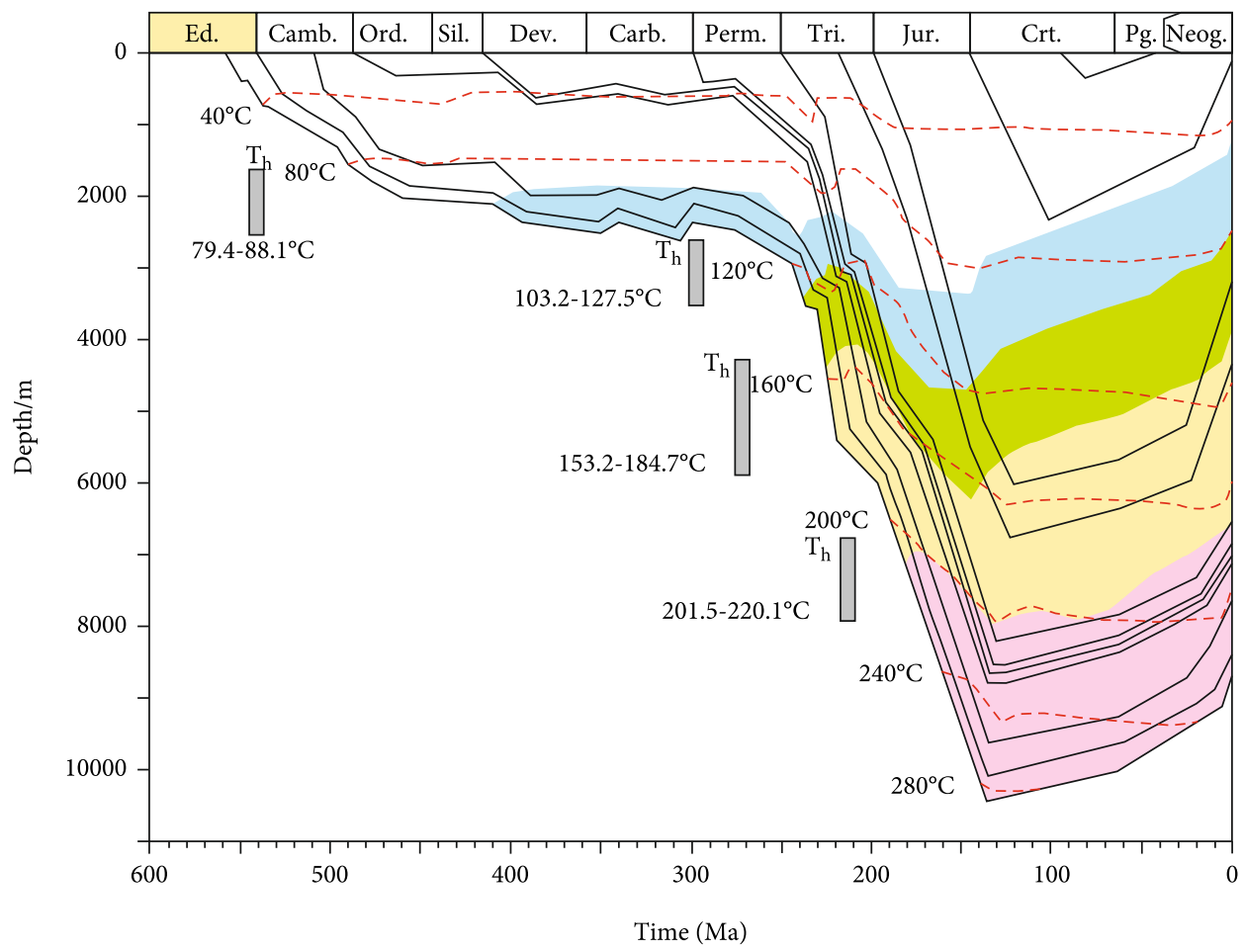

(a)

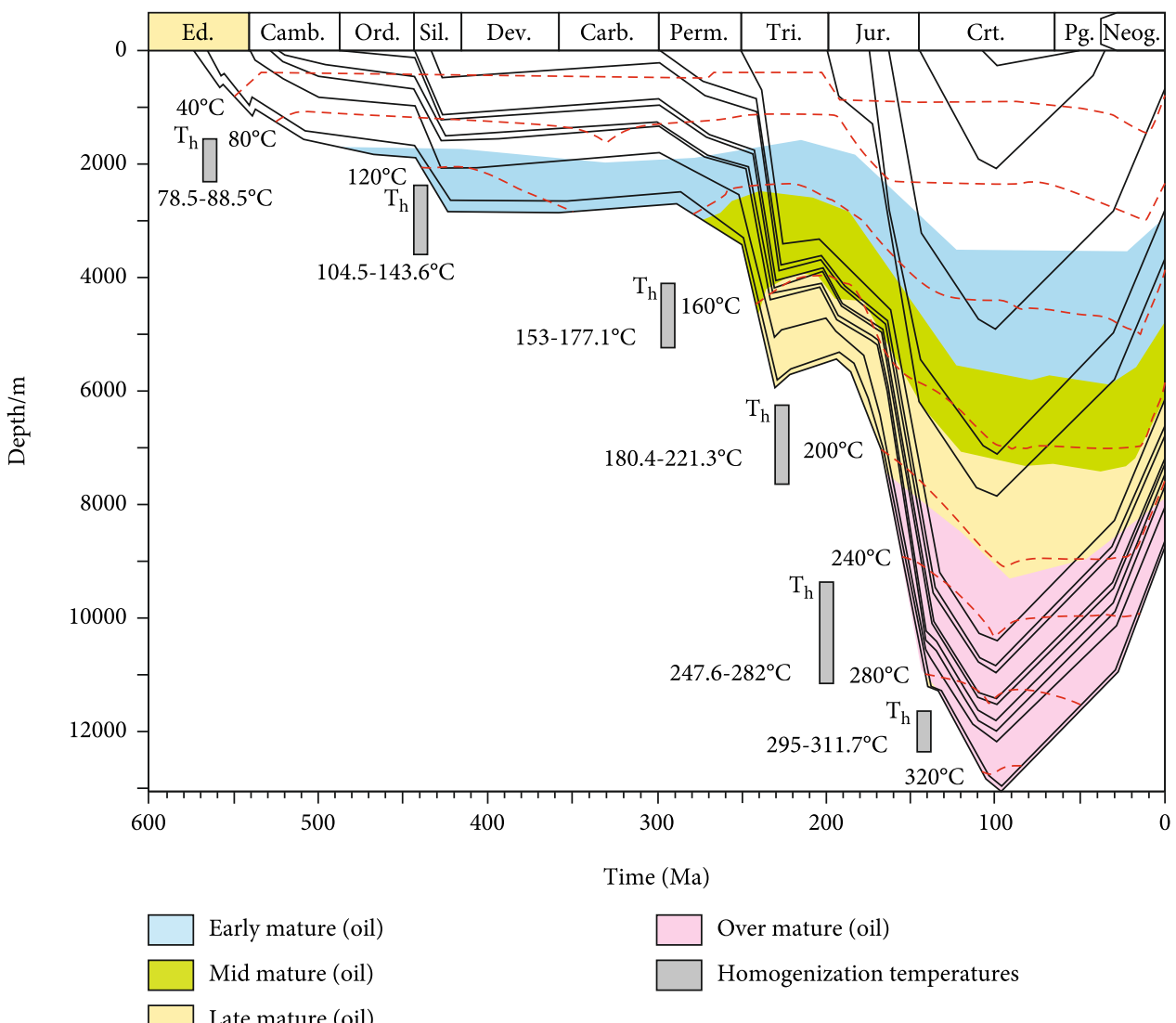

(b)

FIGURE 9: Burial thermal history of the two wells of the Sinian Dengying Formation: (a) CS well \#1; (b) MS well \#1, indicating approximately similar burial and thermal histories. 
TABLE 3: Main source rock formation properties of the two wells. TOC: wt.\% total organic carbon; Ro: vitrinite reflectance.

\begin{tabular}{|c|c|c|c|c|c|}
\hline Well & Depth $(\mathrm{m})$ & Formation & Lithology & TOC (wt.\%) & Ro $(\%)$ \\
\hline \multirow{6}{*}{ CS well \#1 } & 7,137 & $S_{1} l$ & Black siliceous shale & 2.32 & 2.01 \\
\hline & 7,143 & $S_{1} l$ & Black carbonaceous shale & 4.20 & 2.09 \\
\hline & 7,149 & $S_{1} l$ & Black carbonaceous shale & 4.36 & 2.14 \\
\hline & 7,956 & $\epsilon_{1} q$ & Black siliceous shale & 1.70 & 2.08 \\
\hline & 8,110 & $\epsilon_{1} q$ & Black carbonaceous shale & 3.18 & 2.15 \\
\hline & 8,127 & $\epsilon_{1} q$ & Black carbonaceous shale & 2.23 & 2.22 \\
\hline \multirow{7}{*}{ MS well \#1 } & 6,890 & $S_{1} l$ & Black siliceous shale & 0.71 & 2.21 \\
\hline & 6,916 & $S_{1} l$ & Black carbonaceous shale & 1.39 & 2.23 \\
\hline & 6,924 & $S_{1} l$ & Black carbonaceous shale & 4.06 & 2.87 \\
\hline & 7,970 & $\epsilon_{1} q$ & Grey-black siliceous shale & 3.66 & 4.3 \\
\hline & 7,990 & $\epsilon_{1} q$ & Black siliceous shale & 4.25 & 4.59 \\
\hline & 8,006 & $\epsilon_{1} q$ & Black carbonaceous shale & 3.23 & 4.29 \\
\hline & 8,026 & $\epsilon_{1} q$ & Black carbonaceous shale & 6.04 & 4.65 \\
\hline
\end{tabular}

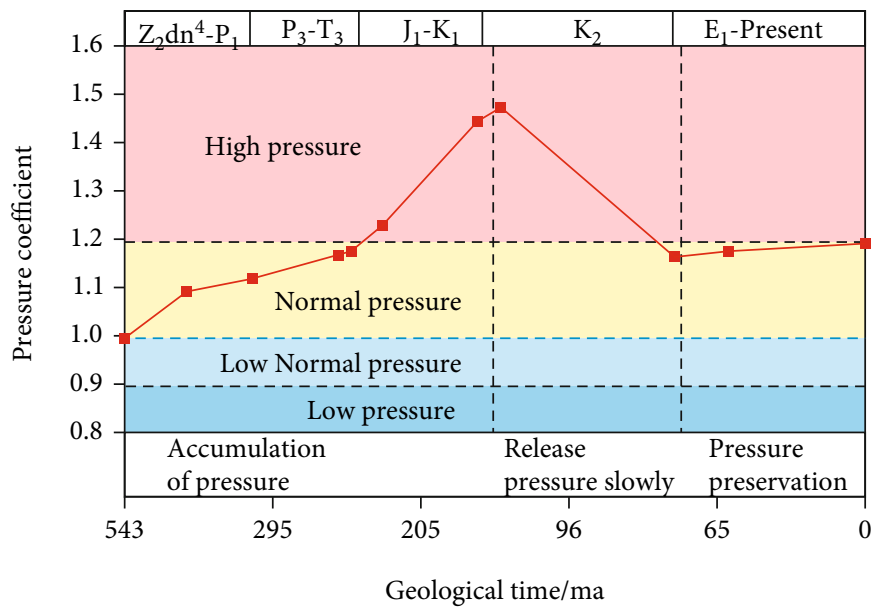

(a)

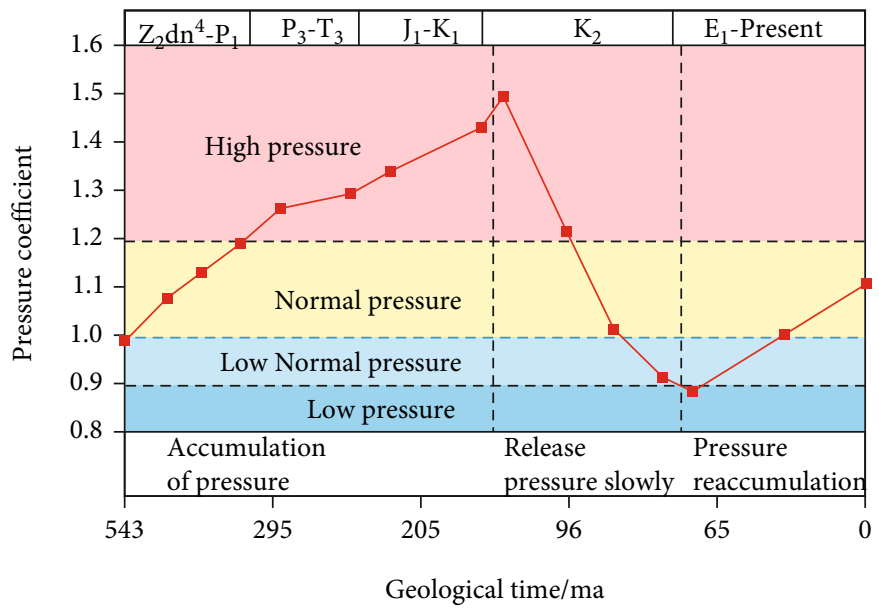

(b)

Figure 10: Palaeo-pressure evolution histories of the $\mathrm{Z}_{2} \mathrm{dn}^{4}$ member in the two wells: (a) CS well \#1; (b) MS well \#1, indicating a highpressure palaeo-gas reservoir (i.e., pressure coefficient $>1.5$ ) before the Late Cretaceous period followed by different processes in the Cenozoic. 


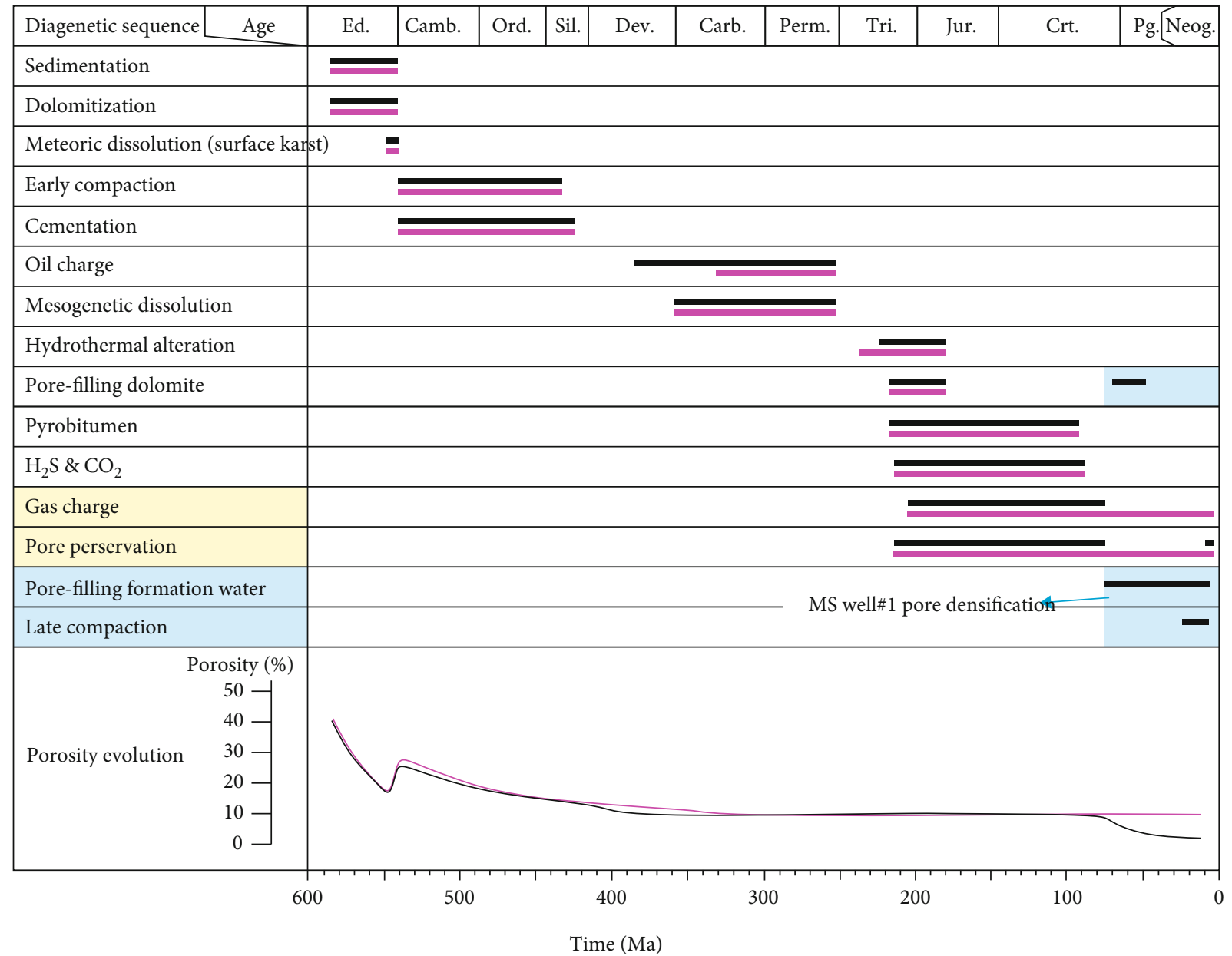

- MS well \#1

— CS well \#1

Figure 11: Diagenetic sequence and porosity development in the Sinian $\mathrm{Z}_{2} \mathrm{dn}^{4}$ member during the formation of dolomite reservoirs. Note that differential porosity evolution occurred in the Cenozoic between MS well \#1 and CS well \#1.

(Figure 11); this resulted in better original porosity in the early reservoirs of CS well \#1 and MS well \#1.

In particular, the unconformity at the top of the CS well \#1 in the Dengying Formation at a depth of $8,146 \mathrm{~m}$ resulted in the development of solution pores. Therefore, early meteoric dissolution in the upper Yangtze platform caused the formation of many karst cavities in both MS well \#1 and CS well \#1 $\mathrm{Z}_{2} \mathrm{dn}^{4}$ members, resulting in high-quality porosity (Figure 11).

With the deep burial of dolomite, compaction and early cementation strongly reduced the porosity of the dolomite reservoir. Late Silurian-Triassic crude oil from the Lower Cambrian source rocks migrated into the reservoir pores of the Dengying Formation $[29,56]$. The Permian period was affected by the Emei movement, with hydrothermal events occurring in the dolomites of the Dengying Formation in the Sichuan Basin, resulting in slight modification of the secondary solution pores $[57,58]$. Since the Jurassic, as the burial depth and geothermal temperature increased, the crude oil in the pores of the Dengying Formation cracked into gas, forming a palaeo-gas reservoir. To date, the pores of the two drilling wells in the Dengying Formation dolomite reservoirs experienced similar diagenesis. Until the Late Cretaceous, as a result of the Himalayan movement in the Sichuan Basin, both wells of the Dengying Formation experienced changes in the dynamic preservation of oil and gas reservoirs, which indirectly led to differences in their reservoir pore preservation conditions.

\subsection{Genetic Mechanisms of Bitumen with Different Pore Geometries}

6.2.1. Bitumen Geometry. The filling minerals in the CS well \#1 pores are mostly recrystallised dolomite and bitumen (Figures 2(c) and 2(d) and Figures 4(c)-4(h)), with bitumen as the final filling mineral. Therefore, bitumen adheres to the pore wall in an annular shape as a result of the thermal cracking of hydrocarbons. In particular, in situ shrinkage joints are widespread in bitumen. The MS well \#1 pore multistage mineral filling sequence is complex, particularly multistage quartz. The bitumen in the pores of MS well \#1 is predominantly broken, granular, 


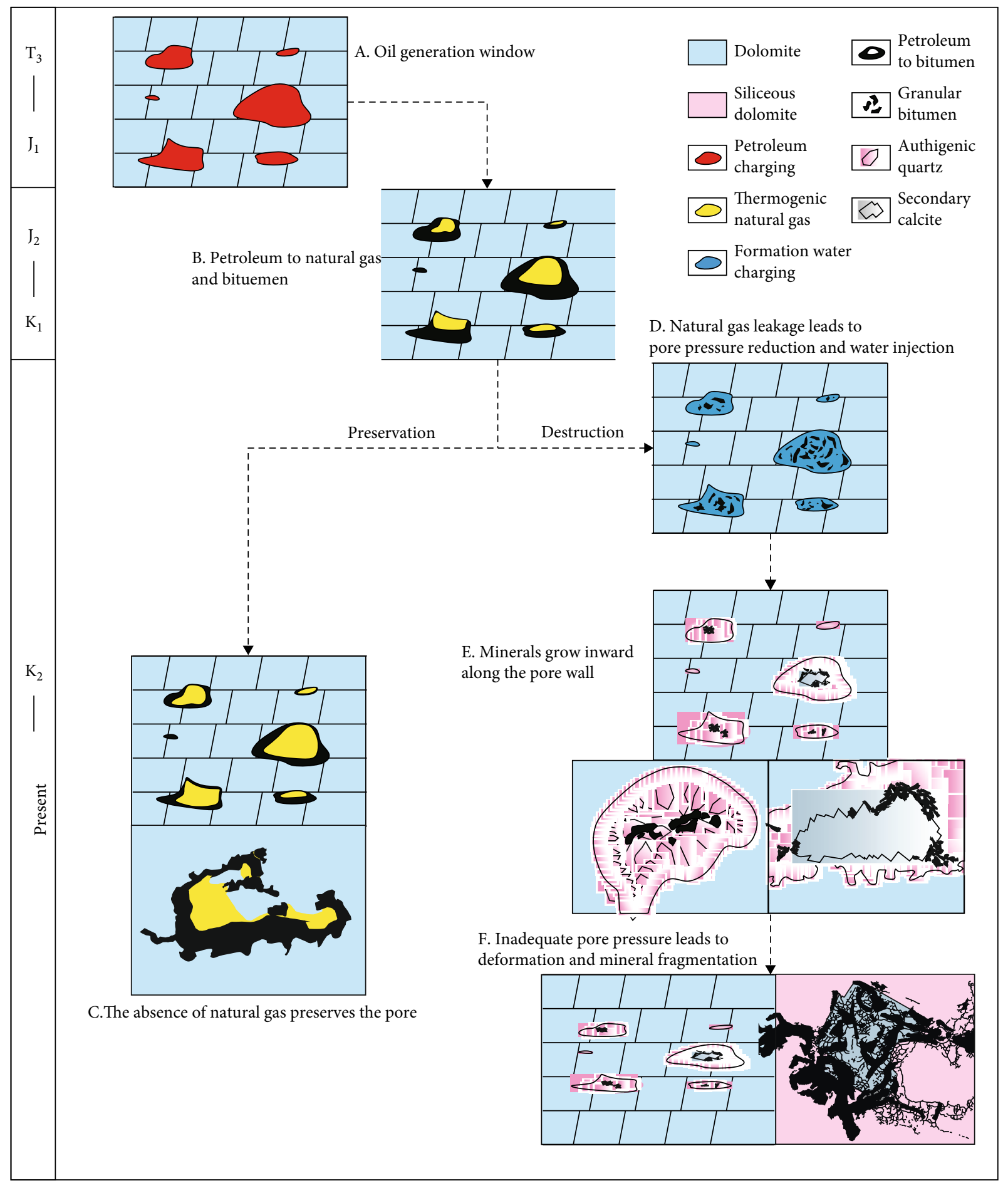

Figure 12: Differential evolution of pores in the $\mathrm{Z}_{2} \mathrm{dn}^{4}$ member in the two wells (modified from [25]). Annular-shaped bitumen with contraction joints in pores of the $Z_{2} \mathrm{dn}^{4}$ reservoir is widespread in CS well \#1, which is attributed to continuous preservation of the CS well \#1 palaeo-gas reservoir. In contrast, broken granular bitumen is scattered in pores with authigenic quartz in MS well \#1, indicating significant destruction and dissipation of the palaeo-gas field in MS well \#1.

and scattered in or between the crystals of various pore epigenetic minerals (Figures 3(c) and 3(d) and Figures 5(a)-5(d)). It should be noted that the bitumen particles are embedded in the crystal boundary with distinct ruptures (Figures 5(b), 5(d), 5(e), 5(g), and 5(j)).
6.2.2. Bitumen Mechanics of Bitumen with Different Geometry. CS well \#1 and MS well \#1 underwent deep burial processes, resulting in widespread pyrolysis of hydrocarbon substances in the reservoir to form carbonaceous bitumen. Therefore, we suggest that two genetic processes led to the 
formation of different bitumen geometries in MS well \#1. (1) Tectonic movement resulted in deformation of the host strata and bitumen formation in pores, as well as the aggregation of broken bitumen particles at the bottom of pores. (2) Late fluid intrusion into the pores of the reservoir resulted in the breakage of bitumen on the cave wall, accompanied by the precipitation and growth of minerals in the fluid. Thus, the bitumen particles are either incorporated into the new mineral crystals or gradually pushed to the intercrystalline phase during mineral growth. According to our thin-section and FESEM observations, we prefer the latter process to account for the observed geometries of bitumen in the CS well \#1 and MS well \#1.

6.2.3. Correlation between Bitumen Geometry and Pore Evolution. The two wells experienced the same events: crude oil filling and thermal cracking into gas from the Triassic and Early Jurassic-Early Cretaceous. Since the Late Cretaceous, the palaeo-pressure and related preservation conditions of the CS well \#1 and MS well \#1 $\mathrm{Z}_{2} \mathrm{dn}^{4}$ member were different.

CS well \#1 is located on the low and gentle northern slopes of central Sichuan. Owing to the lack of strong deformation, the early oil and gas reservoirs exhibited good preservation conditions with overpressure. This effectively prevented other fluids from entering the pores and is consistent with the annular bitumen shape and shrinkage joints in CS well \#1 (Figure 2(e) and Figures 4(a), 4(c), and 4(f)). Thus, we infer that the crude oil was not disturbed or transformed by other fluids after thermal cracking into carbonaceous bitumen (Figure 12(c)). Conversely, MS well \#1 is located in the foreland of the Micang Mountain, dominated by strong deformation and rapid erosion since the Late Cretaceous, which destroyed the preservation and depletion of gas in the MS well \#1 Dengying Formation. The depleted natural gas provided space for other fluids in the pores. Large-scale fluid flowed rapidly into the pores (the homogenisation temperature of inclusions was $247.6-282^{\circ} \mathrm{C}$ ), resulting in the disturbance and fragmentation of bitumen in the pores (Figure 12(d)). Overall, the fluid minerals in the pores were filled, grown, and enclosed in broken bitumen particles. At the same time, with the growth of mineral crystals, bitumen particles were pushed to the crystal boundary (Figures 5(a)-5(f) and Figures 12(e)).

The palaeo-pressure coefficient of CS well \#1 was 1.11.5, indicating overpressure in the Dengying Formation (Figure 10(b)). In the Cenozoic, the palaeo-pressure coefficient remained at approximately 1.2, indicating that this abnormal pore pressure could still support the overlying strata and maintain the pores (Figure 2(e) and Figure $12(\mathrm{c}))$. However, the abnormal pore pressure of MS well \#1 decreased rapidly from a pressure coefficient of 1.5 in the Late Cretaceous, to a weak normal pressure of approximately 1.0 in the Cenozoic. Under such a weak normal pressure state, compaction of the overlying strata would affect the reservoir pores, resulting in densification of the reservoir (Figure 3(f) and Figures 5(d)-5(f)). Therefore, compaction during the late-stage diagenesis of MS well \#1 led to extrusion fracture of the boundary between the crys- tals of some epigenetic minerals in the pores (Figures 5(d)$5(\mathrm{~g}))$, with even crushed quartz particles becoming embedded in the bitumen (Figure 5(j) and Figure 12(f)).

In summary, the $Z_{2} \mathrm{dn}^{4}$ member reservoirs sampled in CS well \#1 and MS well \#1 experienced similar diagenesis prior to the Late Cretaceous, in the form of microbial mat construction, dolomitisation, karst weathering, crude oil filling, and dissolution during the burial period. However, the diagenesis stages of the two wells differed in the natural gas preservation stage (Figure 11). The long-term effective preservation of the CS well \#1 natural gas reservoir resulted in intact pores (Figure 12(c)). Since the Late Cretaceous, MS well \#1 experienced rapid gas depletion with water entering the pores and mineralisation, resulting in pore densification (Figure 12(e)). As a result, the palaeo-pressure decreased rapidly with the depletion of natural gas, which led to further compaction of pores in the reservoirs (Figure 12(f)).

\section{Conclusions}

(1) The carbonate reservoirs in the $Z_{2} \mathrm{dn}^{4}$ member of CS well \#1 and MS well \#1 are dominated by microbial algal dolomite. The $\mathrm{Z}_{2} \mathrm{dn}^{4}$ reservoir of MS well \#1 exhibits more complex pore diagenesis and poorer reservoir physical properties than that of CS well \#1

(2) Dynamic adjustment of the Dengying Formation palaeo-gas reservoir indirectly affects the preservation or failure of the reservoir. The palaeo-gas and pore normal pressure $(1.1-1.2)$ of the CS well \#1 Dengying Formation were preserved, which effectively prevented other ore-forming fluids from entering and filling the pores. Conversely, the palaeo-gas of MS well \#1 was destroyed and depleted, which allowed other ore-forming fluids to enter and fill the pores; thus, the abnormal pore pressure decreased rapidly from a pressure coefficient of 1.5 to a weak normal pressure (slightly less than 1.0), resulting in further compaction of the pores

(3) The pore morphology and geometry of reservoir bitumen can be used as effective indicators of the level of preservation or destruction of the reservoir pores. Annular-shaped bitumen with contraction joints in reservoir pores is widespread in CS well \#1, which is consistent with the continuous preservation of palaeo-gas fields. In contrast, broken particles of bitumen scattered among the epigenetic minerals are widespread in MS well \#1, which is consistent with multistage minerals and a reduced pressure coefficient in the reservoirs, indicating failure and depletion of palaeo-gas fields

\section{Data Availability}

State Key Laboratory of Oil and Gas Reservoir Geology and Exploitation, Chengdu University of Technology, Chengdu, Sichuan 610059, China. 


\section{Conflicts of Interest}

The authors declare that they have no conflicts of interest.

\section{Acknowledgments}

This work was supported by the Natural Science Foundation (no. U19B6003), the Youth Natural Science Foundation (no. 41902105), the National Basic Research Program of China (no. 2017ZX05005-003-007), and Sichuan Province Foundation of China (no. 2018JZ0078).

\section{References}

[1] C. Garing, L. Luquot, P. A. Pezard, and P. Gouze, "Electrical and flow properties of highly heterogeneous carbonate rocks," AAPG Bulletin, vol. 98, pp. 49-66, 2014.

[2] Q. Luo, C. Zhang, Q. Dai et al., "Characterization of compact carbonate pore-throat network systems in the Xiagou Formation in Qingxi Sag, Jiuquan Basin, China," Journal of Petroleum Science and Engineering, vol. 159, pp. 853-868, 2017.

[3] L. Wang, S. Yang, X. Peng et al., "An improved visual investigation on gas-water flow characteristics and trapped gas formation mechanism of fracture-cavity carbonate gas reservoir," Journal of Natural Gas Science \& Engineering, vol. 49, pp. 213-226, 2018.

[4] K. Zhang, X. Q. Pang, Z. F. Zhao et al., "Pore structure and fractal analysis of Lower Carboniferous carbonate reservoirs in the Marsel area, Chu-Sarysu basin," Marine and Petroleum Geology, vol. 93, pp. 451-467, 2018.

[5] V. Kutcherov, "Theory of abyssal abiotic petroleum origin: challenge for petroleum industry," AAPG European Region Newsletter, vol. 3, pp. 2-4, 2008.

[6] Y. Ma, M. Li, X. Cai et al., "Mechanisms and exploitation of deep marine petroleum accumulations in China: advances technological bottlenecks and basic scientific problems," Oil \& Gas Geology, vol. 41, no. 4, pp. 655-672, 2020.

[7] G. Zhu, T. Wang, Z. Xie, B. Xie, and K. Liu, "Giant gas discovery in the precambrian deeply buried reservoirs in the Sichuan basin, China: implications for gas exploration in old cratonic basins," Precambrian Research, vol. 262, pp. 45-66, 2015.

[8] C. Guo, D. Chen, H. Qing et al., "Multiple dolomitization and later hydrothermal alteration on the Upper Cambrian-Lower Ordovician carbonates in the northern Tarim Basin, China," Marine and Petroleum Geology, vol. 72, pp. 295-316, 2016.

[9] L. Wang, Y. He, X. Peng, H. Deng, Y. Liu, and W. Xu, "Pore structure characteristics of an ultradeep carbonate gas reservoir and their effects on gas storage and percolation capacities in the Deng IV member, Gaoshiti-Moxi Area, Sichuan Basin, SW China," Marine and Petroleum Geology, vol. 111, pp. 44$65,2020$.

[10] J. W. Schmoker and R. B. Halley, "Carbonate porosity versus depth: a predictable relation for South Florida," AAPG Bulletin, vol. 66, pp. 2561-2570, 1982.

[11] S. N. Ehrenberg and P. H. Nadeau, "Sandstone vs. carbonate petroleum reservoirs. A global perspective on porosity-depth and porosity-permeability relationships," AAPG Bulletin, vol. 89, no. 4, pp. 435-445, 2005.

[12] L. Neveux, D. Grgic, C. Carpentier, J. Pironon, L. Truche, and J. P. Girard, "Experimental simulation of chemomechanical processes during deep burial diagenesis of carbonate rocks,"
Journal of Geophysical Research: Solid Earth, vol. 119, no. 2, pp. 984-1007, 2014.

[13] C. F. Cai, W. X. He, L. Jiang, K. Li, L. Xiang, and L. Q. Jia, "Petrological and geochemical constraints on porosity difference between Lower Triassic sour- and sweet-gas carbonate reservoirs in the Sichuan Basin," Marine and Petroleum Geology, vol. 56, pp. 34-50, 2014.

[14] Z. Jin, D. Zhu, W. Hu, X. Zhang, J. Zhang, and Y. Song, "Mesogenetic dissolution of the middle Ordovician limestone in the Tahe oilfield of Tarim basin, NW China," Marine and Petroleum Geology, vol. 26, no. 6, pp. 753-763, 2009.

[15] S. N. Ehrenberg, O. Walderhaug, and K. Bjørlykke, "Carbonate porosity creation by mesogenetic dissolution: reality or illusion?," AAPG Bulletin, vol. 96, no. 2, pp. 217-233, 2012.

[16] S. Emmanuel and B. Berkowitz, "Effects of pore-size controlled solubility on reactive transport in heterogeneous rock," Geophysical Research Letters, vol. 34, no. 6, pp. 1-5, 2007.

[17] D. Zhu, Q. Liu, J. Zhang, Q. Ding, Z. He, and X. Zhang, “Types of fluid alteration and developing mechanism of deep marine carbonate reservoirs," Geofluids, vol. 2019, Article ID 3630915, 18 pages, 2019.

[18] L. Jiang, C. Cai, R. H. Worden et al., "Rare earth element and yttrium (REY) geochemistry in carbonate reservoirs during deep burial diagenesis: implications for REY mobility during thermochemical sulfate reduction," Chemical Geology, vol. 415, pp. 87-101, 2015.

[19] S. J. Li, D. S. Sun, M. L. Zheng, and X. W. Meng, "Salt-related structure and its control on hydrocarbon of the Cambrian in Sichuan basin,” Oil \& Gas Geology, vol. 35, p. 622, 2014.

[20] I. Al-Aasm, "Origin and characterization of hydrothermal dolomite in the Western Canada Sedimentary Basin," Journal of Geochemical Exploration, vol. 78-79, pp. 9-15, 2003.

[21] L. B. J. Smith, "Origin and reservoir characteristics of upper Ordovician Trenton-Black River hydrothermal dolomite reservoirs in New York," AAPG Bulletin, vol. 90, no. 11, pp. 1691-1718, 2006.

[22] K. Bjørlykke and J. Jahren, "Open or closed geochemical systems during diagenesis in sedimentary basins: constraints on mass transfer during diagenesis and the prediction of porosity in sandstone and carbonate reservoirs," AAPG Bulletin, vol. 96, no. 12, pp. 2193-2214, 2012.

[23] H. Fang, X. Zhang, C. Wang et al., "The fate of $\mathrm{CO}_{2}$ derived from thermochemical sulfate reduction (TSR) and effect of TSR on carbonate porosity and permeability, Sichuan Basin, China," Earth-Science Reviews, vol. 141, pp. 154-177, 2015.

[24] L. B. J. Smith and G. R. Davies, "Structurally controlled hydrothermal alteration of carbonate reservoirs: introduction," AAPG Bulletin, vol. 90, no. 11, pp. 1635-1640, 2006.

[25] S. G. Liu, W. Sun, Y. H. Zhao et al., "Differential accumulation and distribution of natural gas and its main controlling factors in the Sinian Dengying Fm, Sichuan Basin," Natural Gas Industry B, vol. 2, pp. 24-36, 2015.

[26] C. Zou, J. Du, C. Xu et al., "Formation, distribution, resource potential, and discovery of Sinian-Cambrian giant gas field, Sichuan Basin, SW China," Petroleum Exploration and Development, vol. 41, no. 3, pp. 306-325, 2014.

[27] S. G. Liu, Z. Q. Li, B. Deng et al., "Occurrence morphology of bitumen in Dengying formation deep and ultra-deep carbonate reservoirs of the Sichuan Basin and its indicating significance to oil and gas reservoirs," Natural Gas Industry, vol. 41, no. 8, pp. 102-112, 2021. 
[28] Y. S. Ma, C. L. Mu, and T. L. Guo, "Sequence stratigraphy and reservoir distribution of the Changxing formation in northeastern Sichuan basin," Earth Science Frontiers, vol. 12, pp. 179-185, 2005.

[29] Z. J. Zhao, Y. Zhu, H. Y. Deng, and Y. J. Xu, "Control of palaeo-uplift to the Meso Palaeozoic primary oil and gas pools in the south of China," Petroleum Geology and Experiment, vol. 25, pp. 10-17, 2003.

[30] X. H. Li, "U-Pb zircon ages of granites from the southern margin of the Yangtze block: timing of Neoproterozoic Jinning orogeny in SE China and implications for Rodinia assembly," Precambrian Research, vol. 97, pp. 43-57, 1999.

[31] M. F. Zhou, D. P. Yan, P. M. Vasconcelos, J. W. Li, and R. Z. $\mathrm{Hu}$, "Structural and geochronological constraints on the tectono-thermal evolution of the Danba domal terrane, eastern margin of the Tibetan Plateau," Journal of Southeast Asian Earth Sciences, vol. 33, no. 5-6, pp. 414-427, 2008.

[32] F. H. Hou, S. X. Fang, X. Z. Wang, J. X. Huang, and L. Li, "Further understandings of the gas-reservoir rocks of Sinian Dengying formation in Sichuan, China," Acta Petrolei Sinica, vol. 20, pp. 16-22, 1999.

[33] B. C. Burchfiel, Z. Chen, Y. Liu, and L. H. Royden, "Tectonics of the Longmen Shan and adjacent regions, central China," International Geology Review, vol. 37, no. 8, pp. 661-735, 1995.

[34] Z. Jin, Y. Yuan, Q. Liu, and Y. Wo, "Controls of Late JurassicEarly Cretaceous tectonic event on source rocks and seals in marine sequences, South China," Science China Earth Sciences, vol. 56, no. 2, pp. 228-239, 2013.

[35] S. G. Liu, C. Qin, L. Jansa et al., "Transformation of oil pools into gas pools as results of multiple tectonic events in Upper Sinian (Upper Neoproterozoic), deep part of Sichuan Basin, China," Energy Exploration \& Exploitation, vol. 29, no. 6, pp. 679-698, 2011.

[36] S. G. Liu, Y. Yang, B. Deng et al., "Tectonic evolution of the Sichuan Basin, Southwest China," Earth-Science Reviews, vol. 213, article 103470, 2021.

[37] G. Q. Wei, G. S. Chen, S. M. Du, L. Zhang, and W. Yang, "Petroleum systems of the oldest gas field in China: Neoproterozoic gas pools in the Weiyuan gas field, Sichuan Basin," Marine and Petroleum Geology, vol. 25, pp. 371-386, 2008.

[38] S. G. Liu, B. Deng, Z. W. Li, and W. Sun, "Architecture of basin-mountain systems and their influences on gas distribution: a case study from the Sichuan basin, South China," Journal of Asian Earth Sciences, vol. 47, pp. 204-215, 2012.

[39] J. Q. Wang, "Relationship between tectonic evolution and hydrocarbon in the foreland of the Longmen mountains," Journal of Southeast Asian Earth Sciences, vol. 13, no. 3-5, pp. 327-336, 1996.

[40] J. H. Du, Z. C. Wang, C. N. Zhou et al., Geologic Theory and Exploration Practice of Ancient Large Carbonates Gas Field, Petroleum Industry Press, 2015.

[41] Z. W. Li, S. G. Liu, H. D. Chen et al., "Spatial variation in Meso-Cenozoic exhumation history of the Longmen Shan thrust belt (eastern Tibetan Plateau) and the adjacent western Sichuan basin: constraints from fission track thermochronology," Journal of Asian Earth Sciences, vol. 47, pp. 185-203, 2012.

[42] J. G. Wang, D. Z. Chen, D. Wang, D. T. Yan, Z. Q. Zhou, and Q. C. Wang, "Petrology and geochemistry of chert on the marginal zone of Yangtze Platform, western Hunan, South China, during the Ediacaran-Cambrian transition," Sedimentary, vol. 59, no. 3, pp. 809-829, 2012.

[43] X. Q. Shan, J. Zhang, B. M. Zhang et al., "Characteristics of dolomite karstic reservoir in the Sinian Dengying Formation, Sichuan Basin," Petroleum Research, vol. 2, no. 1, pp. 13-24, 2017.

[44] M. Jin, X. Tan, S. Tong et al., "Karst paleogeomorphology of the fourth Member of Sinian Dengying Formation in Gaoshiti-Moxi area, Sichuan Basin, SW China: restoration and geological significance," Petroleum Exploration and Development, vol. 44, no. 1, pp. 58-68, 2017.

[45] D. Chen, X. Zhou, Y. Fu, J. Wang, and D. Yan, "New U-Pb zircon ages of the Ediacaran-Cambrian boundary strata in South China," Terra Nova, vol. 27, no. 1, pp. 62-68, 2015.

[46] Y. Ding, D. Chen, X. Zhou, C. Guo, T. Huang, and G. Zhang, "Cavity-filling dolomite speleothems and submarine cements in the Ediacaran Dengying microbialites, South China: responses to high-frequency sea-level fluctuations in an 'aragonite-dolomite sea', Sedimentology, vol. 66, no. 6, pp. 2511-2537, 2019.

[47] L. W. Diamond, "Review of the systematics of $\mathrm{CO}_{2}-\mathrm{H}_{2} \mathrm{O}$ fluid inclusions," Lithos, vol. 55, no. 1-4, pp. 69-99, 2001.

[48] W. Lu, I. M. Chou, R. C. Burruss, and Y. Song, "A unified equation for calculating methane vapor pressures in the $\mathrm{CH}_{4}-\mathrm{H}_{2} \mathrm{O}$ system with measured Raman shifts," Geochimica et Cosmochimica Acta, vol. 71, no. 16, pp. 3969-3978, 2007.

[49] M. F. Weldeghebrie, T. K. Lowenstein, J. García-Veigas, D. Collins, and I. Sirota, "Combined la-icp-ms and cryosem-eds: an improved technique for quantitative analysis of major, minor, and trace elements in fluid inclusions in halite," Chemical Geology, vol. 551, 2020.

[50] K. Amrouch, N. Beaudoin, O. Lacombe, N. Bellahsen, and J. M. Daniel, Evolution of palaeostress magnitudes and pore fluid pressure during folding above a basement thrust: an integrated mechanical study at Sheep Mountain anticline, AGU, Wyoming, USA, 2011.

[51] R. J. Bodnar, "Revised equation and table for determining the freezing point depression of $\mathrm{H}_{2} \mathrm{O}-\mathrm{Nacl}$ solutions," Geochimica et Cosmochimica Acta, vol. 57, no. 3, pp. 683-684, 1993.

[52] N. Beaudoin, O. Lacombe, N. Bellahsen, K. Amrouch, and J. M. Daniel, "Evolution of pore-fluid pressure during folding and basin contraction in overpressured reservoirs: insights from the Madison-Phosphoria carbonate formations in the Bighorn Basin (Wyoming, USA)," Marine \& Petroleum Geology, vol. 55, pp. 214-229, 2014.

[53] Y. G. Zhang and J. D. Frantz, "Determination of the homogenization temperatures and densities of supercritical fluids in the system $\mathrm{NaCl}-\mathrm{KCl}-\mathrm{CaCl}_{2}-\mathrm{H}_{2} \mathrm{O}$ using synthetic fluid inclusions," Chemical Geology, vol. 64, no. 3-4, pp. 335-350, 1987.

[54] J. J. Sweeney and A. K. Burnham, "Evaluation of a simple model of vitrinite reflectance based on chemical kinetics," AAPG Bulletin, vol. 74, pp. 1559-1570, 1990.

[55] A. K. Burnham, R. L. Braun, H. R. Gregg, and A. M. Samoun, "Comparison of methods for measuring kerogen pyrolysis rates and fitting kinetic parameters," Energy \& Fuels, vol. 1, no. 6, pp. 452-458, 1987.

[56] S. J. Li, B. Gao, Y. J. Wo, Y. Zhou, and Y. S. Yuan, "Destruction types and temporalspatial distribution of marine hydrocarbon reservoirs in South China," Petroleum Geology and Experiment, vol. 33, pp. 43-55, 2011. 
[57] Q. Liu, D. Zhu, Z. Jin, C. Liu, D. Zhang, and Z. He, "Coupled alteration of hydrothermal fluids and thermal sulfate reduction (TSR) in ancient dolomite reservoirs - an example from Sinian Dengying Formation in Sichuan Basin, southern China," Precambrian Research, vol. 285, pp. 39-57, 2016.

[58] S. Liu, W. Huang, C. Chen et al., "Primary study on hydrothermal fluid activities and its effectiveness on petroleum and mineral accumulation of Sinian system - Palaeozoic in Sichuan basin," Journal of Mineralogy and Petrology, vol. 28, pp. 4150, 2008. 